\title{
Konstruktivistické teorie učení a jejich využití v edukační realitě muzea
}

\author{
Veronika Kolaříková \\ Masarykova univerzita, Pedagogická fakulta \\ Redakci zasláno 15. 5. 2018 / upravená verze obdržena 13. 9. 2018 / \\ / k uveřejnění přijato 16. 9. 2018
}

\begin{abstract}
Abstrakt: Edukace je součástí nejen školního prostředí, ale i prostředí dalších institucí, mezi které se dnes výraznou měrou řadí muzea. Ta mohou edukovat a kultivovat své návštěvníky, přičemž vhodným ukotvením muzejněedukačních aktivit se zdají být konstruktivistické teorie učení. Ty vycházejí z konstruktivistického paradigmatu sociálních věd i myšlenek klasiků, jako je např. Dewey. Představení konstruktivistických teorií učení, jejich ukotvení v konstruktivistickém paradigmatu i jejich následná aplikace do prostředí muzea tvoří klíčovou osu i téma předkládané studie. Hlavním cílem studie ale není pouze představit konstruktivisticky orientovanou muzejní edukaci, ale především vymezit a definovat základní prvky konstruktivistických teorií učení, které mohou být využitelné (nejen) pro muzejněedukační realitu, její praxi i následnou evaluaci.
\end{abstract}

Klíčová slova: konstruktivismus, konstruktivistické teorie učení, edukace, muzeum

Lidé se ve svém životě neustále něčemu učí. Proces učení a výchovy je provází celým životem, nejen dětstvím, které je jako období intenzivní edukace veřejností i v odborné literatuře nejvíce akcentováno. Fakt, že je edukace procesem odehrávajícím se po dobu celého života jedince a procesem, který se netýká pouze prostředí rodiny a školy, ale i dalších institucí, si v současnosti na poli pedagogických a sociálních věd uvědomujeme, a proto se stále více setkáváme s pojmy, jakými jsou informální učení, rekvalifikace, celoživotní učení, edutainment apod. V oblasti pedagogiky věnující pozornost mimoškolnímu prostředí pak sílí hlas muzejní pedagogiky, která se zabývá edukací návštěvníků muzea. Mnohá muzea se dnes snaží být moderními institucemi aktivně se podílejícími na edukaci a kultivaci osobnosti lidí, které do muzea přivádějí nejrůznější pohnutky. At’ už návštěvníci přicházejí do muzea za zábavou, poučením nebo jen chtějí vyplnit čas deštivého dne, vstupují do edukačně podnětného prostředí. 
Muzea uchovávají a prezentují specifické kulturní, historické, přírodovědné, technické, umělecké i jiné objekty, které se podílejí na reprezentaci lidské kultury, na předávání informací i na kultivaci osobnosti návštěvníků. Muzea tak mohou sehrávat důležitou úlohu v komplexním procesu edukace. Edukaci studie chápe jako zastřešující pojem zahrnující v sobě vzájemně se prolínající procesy výchovy a vzdělávání (srov. Průcha, 2002, s. 66; Průcha, Walterová, \& Mareš 2009, s. 63). Jde přitom o procesy mající intencionální povahu (např. edukace odehrávající se v kontextu školního vyučování či edukačního programu muzea) i povahu bezděčnou, kam Průcha $(2002$, s. 66) řadí např. učení nápodobou. $V$ kontextu muzea hovoříme o muzejní edukaci, kterou Šobáňová (2012c, s. 35) vymezuje jako „záměrné, facilitované a intencionální výchovné působení muzea na veřejnost". Muzejní edukace je dle Jagošové, Jůvy a Mrázové (2010, s. 72) jedním z hlavních cílů moderního muzea a „představuje jeden z faktorů, jenž se podílí na rozvoji každého jedince v mnohosti jeho kvalit fyzických, psychických i sociálních". Učení v muzeu může probíhat spontánně. Člověk už jen tím, že muzeum navštíví a sám si jej projde, získává nějaké informace a prožitek. Muzejní edukace může být ale prováděná také cíleně. Snaha muzea edukačně působit na široké spektrum návštěvníků se dnes odráží ve vzrůstajících počtech edukačních programů.

Aby byl edukační výsledek muzejních aktivit co nejefektivnější, je důležité věnovat edukačnímu procesu náležitou odbornou pozornost. Pedagogové, včetně muzejních pedagogů a dalších pracovníků muzea, si kladou otázku, jak efektivně edukační proces $\mathrm{v}$ muzeu realizovat. Významným odborníkem věnujícím se otázce muzejní edukace je George Hein, který se ve svém celoživotním díle zamýšlí nad způsoby muzejní edukace a který prosazuje myšlenku fungování muzeí (především dětských muzeí) jako vzdělávacích institucí. Ideální zázemí pro muzejní edukaci podle Heina (2001) nabízejí konstruktivistické teorie učení. Hein věří, že konstruktivismus nabízí užitečnou vzdělávací teorii založenou na myšlence, že proces učení dětí úzce souvisí s hrou, která je pro ně přirozenou aktivitou. Hlavní důraz konstruktivismus v rámci vzdělávacích teorií klade na pojetí učení jako aktivního procesu, ve kterém učící se jedinci konstruují své poznání. Od této premisy se pak mají edukační aktivity muzea odvíjet.

Důvody, proč je podle Heina (2001) př́nosné v muzeu konstruktivistické teorie využívat, souvisejí především s tím, že nabízejí vzdělávací styl podporující kritické myšlení návštěvníků. Díky tomu podle něj mohou muzea přispívat k rozvoji občanské společnosti oceňující rozmanitost a podporující respekt 
k ostatním. Jako další z kladů konstruktivistických teorií učení shledává jejich návaznost na tradici objektového učení, které je v muzeích využíváno už dlouhou dobu a kteréshodně považuje hru za způsob učení. Konstruktivistické teorie učení jdou ale nad rámec objektového učení a kladou důraz i na další aspekty edukace. Učení podle Heina (2001) chápou jako proces osobní konstrukce významu spíše než jako proces přenosu vědomostí. Z této pozice si uvědomují, že měnit lidské znalosti, názory, postoje, vlastnosti i další osobnostní rysy je velmi složité a nelze očekávat, že pouhé předání informace k jejímu osvojení postačí.

Konstruktivisticky orientovaný edukační proces se do prostředí muzeí hodí, nebot' muzea ze své podstaty tvoří instituce zaměřující se na oblast informálního učení, které zde může probíhat zábavnou a hravou formou, respektive by v ideálním př́ípadě mělo (ačkoli se to tak v praxi vždy a všude neděje), a které zde není pro člověka povinností, ale spíše bonusem. Edukační proces v muzeu není v ideálním př́padě ani tak orientován na to, aby předal návštěvníkovi pevně stanovený výčet určitých informací (i když znalostní potenciál muzeí je veliký a nezanedbatelný), ale aby jej v rámci edukace obohatil také o zkušenosti a př́jemné prožitky a aby kultivoval jeho osobnost v celé její šíri (kultura je v muzeu neustále přítomná a pro edukační proces podstatná). Ve světě také stále více roste důraz na sociální funkce muzea, které se stávají součástí cílů edukačních nebo existují vedle nich. I sociálně orientované cíle pak korespondují s konstruktivisticky orientovanou muzejní edukací. Je přitom samozřejmé, že ve svých edukačních aktivitách muzeum vychází ze svých exponátů, tedy z muzeálií, které jsou základním klíčovým prvkem celého muzejněedukačního procesu, který by bez nich nebyl reálný, a které jsou ze své podstaty spojeny právě s informacemi a znalostmi.

Obsah muzejní edukace vyplývá z povahy muzejních sbírek i charakteristik samotného muzea (typ muzea, velikost muzea a jeho umístění apod.). Zpracování edukačního obsahu pak závisí hlavně na pracovnících muzea a jejich schopnostech a vizích, než že by bylo podřízeno kurikulárním dokumentům, jako je tomu např ve škole. Dnes se přitom často setkáváme se situací, kdy muzea ve snaze získat návštěvníky nabízejí edukační programy šité školám na míru, vystavěné na jejich kurikulu a klíčových kompetencích vycházejících $\mathrm{z}$ rámcových a školních vzdělávacích programů. Omezit edukační působnost na cíle kurikula nebo nekriticky kopírovat klíčové kompetence by ale z hlediska myšlenkového zázemí předkládané studie mohlo být pro muzea spíše nežádoucím jevem, který by je směřoval k rigiditě 
edukačního procesu a nevyužití celého jeho potencionálu, který „pouhý“ znalostní rámec dalekosáhle překračuje. S touto myšlenkou souhlasí i Hein (2001) když ř́ká, že od muzeí nemůžeme čekat, že budou své návštěvníky vzdělávat v takové podobě, která by jim pomohla naplnit přísně stanovený vzdělávací školní obsah, jehož získání by žáci potvrdili vykonáním zkoušek. Muzeum by se podle něj mělo spíše snažit návštěvníky lidsky rozvíjet. A právě k tomuto cíli může konstruktivistické paradigma poskytnout vhodné zázemí. Konstruktivisticky orientovaná edukace totiž není zaměřena jen na zisk informací, ale ze své podstaty se orientuje také na rozvoj osobnosti učícího se jedince (konkrétním příkladem může být důraz kladený na rozvoj kritického myšlení apod.).

Upozorněním na možná rizika nekritického přebírání edukačních cílů vycházejících z rámcových vzdělávacích programů ale netvrdíme, že spolupráce muzea a školy nemůže být pro žáky edukačně obohacující. Naopak, edukace v muzeu může být pro žáky nejen př́jemným zpestřením, ale také přínosem. Podle Heina (cit. podle Savicke \& Juceviciene, 2012, s. 76) mohou muzea školní vzdělávací program obohatit pomocí odlišných vzdělávacích metod. Ty se soustřed'ují na edukaci pomocí exponátů a muzejních narativů, snaží se podněcovat vlastní aktivitu návštěvníka a rozvíjet jeho kritické myšlení, orientují se na jeho zkušenost. A právě zařazení prvků konstruktivistických teorií učení do muzejní edukace může edukační proces obohatit, podpořit a rozvíjet. Orientace v problematice konstruktivisticky laděné edukace tak může být pro pedagogy přínosná. Konstruktivistické paradigma je navíc spojeno s řadou dalších otázek, které se dnes v oblasti pedagogiky (stále) diskutují (napřr. role žáka a učitele v edukačním procesu, vliv edukačního prostředí, důraz na vlastní aktivitu žáků, proces konstrukce znalostí a postojů apod.).

Ve snaze pochopit roli konstruktivistického paradigmatu v oblasti muzejní edukace se ve studii společně podíváme na to, co konstruktivismus v pedagogice vlastně znamená, proč může být dobré jeho paradigmatické zázemí využívat a, především, jak to $\mathrm{v}$ praxi udělat, respektive jak konstruktivismus jako teoretický koncept překlopit do (muzejní) edukační praxe. Právě konkrétní a problematiku shrnující objasnění zavádějící dané téma do samotné muzejněedukační praxe v literatuře často chybí. Cílem textu je tedy (1) představit čtenárưm problematiku konstruktivismu v pedagogické praxi, která se úzce prolíná především s konstruktivistickými teoriemi učení, které je možné využít $v$ edukační realitě muzea. Za tímto účelem bude studie ve svém výkladu postupovat krok za krokem; nejprve poskytne vhled do problematiky 
konstruktivistického paradigmatu a dále zpracuje téma konstruktivistických teorií učení, jež budou následně dány do vztahu s prostředím muzea a muzejní edukace. Studie přitom nechce pouze vysvětlit pozici konstruktivismu v pedagogice a poukázat na to, proč může být př́nosné konstruktivistické prvky v muzejní edukaci využívat, ale především si klade za cíl (2) definovat, jak konkrétně se tyto prvky v muzejní edukaci mohou projevovat. Otevírá se tedy otázka toho, jak je možné konstruktivistické prvky do edukační praxe zapojit, a spolu s tím i problematika toho, jak je možné je výzkumně uchopit při evaluaci edukačních programů. Orientace textu na konkretizaci v edukační praxi využitelných prvků konstruktivistických teorií učení je klíčová. Právě chybějící doporučení v otázce zapojování prvků konstruktivistických teorií učení do edukační praxe totiž mohou vést $\mathrm{k}$ tomu, že je pro (nejen muzejní) pedagogy obtížné s těmito teoriemi pracovat, a proto se jim ve svých aktivitách vyhýbají nebo je využívají jen ojediněle či implicitně, a tím pádem i nahodile a nekoordinovaně. Na základě studia literatury, která bude v textu postupně představována ${ }^{1}$, jako hlavní výstup studie ve svém závěru předloží seznam prvků konstruktivistických teorií učení, které mohou být v muzejní edukaci využívány či analyzovány.

\section{Konstruktivistické paradigma sociálních věd}

Konstruktivismus je široký a různými způsoby používaný pojem. Jeho obsah se odvíjí od toho, zda je pojem používán v rámci sociálních věd jako takových, nebo je blíže specifikován z pozice pedagogiky, sociologie či dalších vědních disciplín. Tím ale není různorodost konstruktivistických přístupů vyčerpána. I v rámci jednoho vědeckého oboru (nejčastěji sociologie) nacházíme celou řadu konstruktivistických přístupů, které se vzájemně liší i prolínají. Konstruktivismus tak můžeme chápat jako určitou meta-teorii, která nabízí specifický pohled nejen na sociální realitu a její konstrukci, ale také na lidské poznání i samotné vědecké teoretizování (Siebert, 2006).

Z této perspektivy by bylo možné předkládanou studii chápat jako přehledovou studii shrnující teoretické př́istupy z oblasti konstruktivistických teorií učení. Zvolené literární zdroje byly vybírány s ohledem na jejich relevanci pro dané téma a kritériem výběru bylo i odborné ukotvení daného zdroje (např. dílo světově či v rámci České republiky uznávaného autora, věnujícího se dané problematice, nebo publikování textu v odborném akademickém časopise, přičemž pro hledání textů byly využity elektronické databáze EBSCO, Web of Science, ProQuest a ERIC). 
Fakt, že konstruktivismus jako populární myšlenkový proud nalézáme napříč různými vědeckými disciplínami, podle Sieberta (2006) pramení z návaznosti konstruktivismu na současnou vysoce pluralitní podobu reality. Konstruktivismus odpovídá potřebám a charakteristikám současné doby proto, že samotné jeho popisy reality jsou rozmanité. Pluralita konstruktivistického pohledu vychází z přesvědčení, že pojetí sociální reality konstruují sociální aktéři. Proto se mohou objevovat různé pohledy na svět, které se pojí se specifickými životními okolnostmi, v nichž sociální aktéři žijí a jednají. Toto pojetí světa pak odpovídá sociologickému konstruktivismu, který označuje souhrn sociologických směrů, škol a koncepcí založených na myšlence sociálního světa jako neustále a kontinuálně konstruovaného sociálními aktéry v procesech sociální komunikace a interakce. Sociální svět nelze vnímat jako z vnějšku daný objektivní fakt, ale jako specifickou sociální konstrukci (Mař́ková, Petrusek, \& Vodáková, 1996, s. 524).

Tradice konstruktivismu je stará (srov. Alieva, 2016; Maříková et al., 1996, s. 524; Siebert, 2006). Prvky konstruktivistického myšlení najdeme už u Kanta, Webera, Marxe, Durkheima, Pareta i dalších významných sociologů. Jako paradigma se sociologický konstruktivismus začal uplatňovat v 60. a 70. letech 20. století a dnes na poli sociálních věd zaujímá významné postavení. Při svém vzniku a formování byl ovlivněn především lingvistickou filozofií (Austin, Wittgenstein), hermeneutikou a v neposlední řadě Schutzem a jeho reinterpretací Husserlova díla. Jako takový se sociologický konstruktivismus odvíjel od kategorie jazyka, jehož náplní není svět pouze popisovat, ale také spoluutvářet, a to nejen prostřednictvím sociální komunikace, ale celkově skrze konstituci sociálního života, tvorbu významů a jejich interpretaci.

Fakt, že konstruktivismus často navazuje na myšlenky sociologických klasiků, podle Sieberta (2006) přispívá k jeho kritice. Někteří autoři konstruktivismu vyčítají, že jeho teze o vztahu mezi světem a člověkem nejsou příliš originální ani nové. Novátorská je podle nich pouze jím používaná terminologie. Výtka směřující k návaznosti stávajících myšlenkových proudů na ty předcházející ale může být dle mého názoru zavádějící. Navazovat na tradiční koncepce, se kterými je badatel obeznámen, není v sociálních vědách ničím neobvyklým, nežádoucím ani strnulým. Navazovat na dosavadní znalosti a dále je zpracovávat totiž neznamená tyto myšlenkové zdroje kopírovat a nekriticky přebírat. Naopak jde o prohlubování těchto myšlenek, jejich další zvažování, kritiku či př́ípadné vymezení se vůči nim. Jedná se tak o přirozený proces 
vědeckého bádání a jeho vývoje, kterým se zabýval už Weber (2009, s. 116), podle kterého není poznání sociálních věd nikdy konečné a definitivní. Vědění, které sociální věda produkuje, je vždy provizorní, v budoucnu může být vždy dále rozvíjeno, reevidováno či zcela překonáno. To by ovšem vědce od jejich bádání nemělo odradit. Navíc vzhledem k tomu, že konstruktivismus netvoří homogenní myšlenkový přístup, lze podle mne tuto kritiku považovat za zjednodušující. Jednotlivé konstruktivistické směry totiž nabízejí různorodé myšlenky, které právě díky tomu, že mohou být rozdílné, mohou být navzájem také o to více diskutovány, promýšleny, upřesňovány a neustále vyjednávány ${ }^{2}$ tak, jak to ostatně od vědecké činnosti sociálních věd vyžadoval už samotný Weber.

Jelikož není konstruktivismus označením pro jediný homogenní pohled na realitu, můžeme rozlišit několik jeho variant. V sociálních vědách se nejčastěji setkáváme s optikou sociálního konstruktivismu, který je spolu s geneticky orientovaným konstruktivismem Piageta a radikálním konstruktivismem (Glasersfeld) také výchozím bodem pro konstruktivismus využívaný v pedagogice. Vedle sociálního, genetického a radikálního konstruktivismu můžeme najít také konstruktivismus biologický (Maturana), filozofický (Schmidt), terapeutický (Watzlawick), neuro-vědecký (Roth), konstruktivismus založený na teoriích sociálních systémů (Luhmann) apod. (srov. Siebert, 2006; Vollmers, 1997).

Přesto, že se konstruktivismus v sociálních vědách rozvětvuje do mnoha specifických podob, můžeme nalézt určité společné myšlenky, které konstruktivisté sdílejí. Jak už bylo naznačeno, základním styčným bodem jednotlivých podob konstruktivismu je fakt, že konstruktivismus představuje teorii poznání vnímající sociální svět jako sociálně konstruovaný. Cílem konstruktivismu není ŕíci, jaký svět je (jedna objektivní a pravdivá realita podle konstruktivismu existovat nemůže, realita je vždy pluralitní), ale spíše popsat, jak jej vnímají a interpretují sociální aktéři. Za tímto účelem dochází k pozorování a analyzování nejen sociální skutečnosti, ale také jednání, myšlení, postojů, znalostí a pocitů lidí. Ti se totiž svým jednáním na konstrukci reality podílejí. Konstrukce sociální reality je proto nevyhnutelně socio-kulturně

Jako dobrý příklad diskuze dvou odlišných směrů konstruktivismu, který je aplikován do oblasti pedagogicky a edukační reality, může posloužit text Kaščáka (2002), který pojednává o rozdílech radikálního „individuálního“ konstruktivismu a „postmoderního“ sociálního konstruktivismu. Oba typy konstruktivismu budou dále v textu pro základní vhled do dané problematiky stručně představeny. 
podmíněná. Aktéři vytvářejí svůj svět na pozadí sociálně-historických zkušeností v sociálně-ekonomických a sociálně-kulturních životních podmínkách a na základě životního stylu specifického pro dané sociální prostředí (Siebert, 2006).

Zabýváme-li se sociálním světem, jeho aktéry a v něm probíhajícími procesy (např. právě procesem edukace), je vhodné si výše popsanou socio-kulturně-historickou kontextuálnost dění a jednání lidí uvědomit. Studie se proto při chápání konstruktivismu a konstruktivistické edukace kloní k optice relacionismu, který vyzdvihuje ve své vědecké práci např. Mannheim zabývající se věděním. Relacionismem má Mannheim (1991, s. 133, 315) na mysli fakt, že vědění a s ním spojené myšlení člověka je vždy ovlivněno socio-kulturním kontextem jeho života a je formováno pod vlivem konkrétní historické epochy a místní kultury (tedy i geografického kontextu), která určuje, co je v dané době známé, co je poznatelné, co je normální apod. Logicky je pak těmito vlivy ovlivněn i proces vzdělávání. Je to totiž socio-kulturní a historický kontext (mohli bychom hovořit i o společenském diskurzu převládajícím ve společnosti apod.), který velkou měrou ovlivňuje to, jaké informace bude muzeum ve svých expozicích a edukačních programech upřednostňovat a prezentovat, a tedy i předkládat svým návštěvníkům. Zároveň, jak si ještě ukážeme, tento kontext ovlivňuje také to, jak budou jednotliví návštěvníci dané informace vnímat a interpretovat.

\section{Sociální konstruktivismus a radikální konstruktivismus}

Podle Al-Saggafa a Williamsonové (2006, s. 7-8) se konstruktivistické paradigma zakládá na dvou hlavních konstruktivistických teoriích. První z nich je Kellyho teorie osobních konstruktů, která klade důraz na individuální realitu a interpretaci světa. V Kellyho podání je jedinec konstruktérem svého pohledu na realitu, a proto neexistuje jedna objektivní realita, nýbrž mnoho pluralitních realit, jejichž podoba se odvíjí od individuálního vnímání reality daného jedince. Druhým pilířem konstruktivistického paradigmatu je Bergerův a Luckmannưv sociální konstruktivismus ${ }^{3}$, jenž v rámci sociální rea-

\footnotetext{
Berger s Luckmannem, byt' stáli u zrodu rozrůstajícího se vlivu sociálního konstruktivismu a jeho využití v sociálních vědách, sami sebe za sociální konstruktivisty neoznačovali a ani se nepovažovali za zakladatele konstruktivistické sociologické školy. Sociální konstrukci reality považovali za samozřejmou skutečnost, od které se sociologické bádání dále odvíjí nebo alespoň v jejich pojetí odvíjet má (srov. Mlynář \& Paulíček, 2016; Paulíček, Mlynář, \& Vido, 2016).
} 
lity a její podoby zdůrazňuje vliv společnosti, kultury a sociálního prostředí. Podoba reality je dle těchto autorů budována lidmi, nikoli však pouhými osamělými jednotlivci, nýbrž lidmi spolu komunikujícími a interagujícími. Jde zde především o kolektivní tvorbu významů zakládající se na jazyce a dalších sociálních procesech, nikoli o problematiku procesu individuální tvorby významů konkrétní mysli, jako tomu je u teorie předchozí.

Podle Bergera s Luckmannem (1999) probíhají konstrukce sociální reality, sociálního vědění a sociální interpretace skrze instituce, jejichž prostřednictvím lidé jednají. Základní premisou je tvrzení, že je realita utvářena sociálně. Pojem realita je proto sociálně relativní, nebot’ lidé pojímají a definují realitu a s ní pojící se vědění různě v závislosti na konkrétním sociálním kontextu, ve kterém se nacházejí. Za cíl své sociologie vědění si pak autoři kladou zkoumat to, jak je utvářeno lidské vědění o realitě v rámci jejich každodenního života. Každodennost je pro autory klíčovým pojmem. Každodenní svět je nejen světem, který „členové společnosti pokládají za danou realitu při svém subjektivním a cílevědomém každodenním jednání. Je to také svět, který má svůj původ v jejich myšlenkách a činnostech a který je právě těmito myšlenkami a činnostmi jako reálný udržován“ (Berger \& Luckmann, 1999, s. 25). Každodenní svět a jeho realita, byt’ se sociálním aktérům jeví jako realita samozřejmá, objektivní a mající předem daný objektivní řád, je těmito aktéry neustále sociálně konstruována. ${ }^{4}$

Na podobě sociální reality se obvykle shodne většina členů dané společnosti a kultury. Lidé dospívají k určité verzi objektivity světa, která je založena na sociální dohodě - tedy na shodě v tom, že svět vypadá tak, jak jej konstruuje většina (Kaščák, 2002, s. 398). A právě díky této sociální shodě, tedy díky přijetí a sdílení shodné konstrukce reality mnoha lidmi, může sociální realita existovat a fungovat. Sociálně konstruovaná a zároveň diskurzivně podmíněná realita pak zpětně sociální aktéry, jejich vědění a jednání ovlivňuje. Dle Kaščáka (2002, s. 401) k tomu dochází především skrze proces enkulturace

Svou teorii ale spíše než jako nový sociologický směr zpracovávali v návaznosti na sociologii vědění. Její problematice se věnovali také ve svém stěžejním díle z roku 1966 s názvem Sociální konstrukce reality, jehož název i obsah onen boom kolem sociálního konstruktivismu podnítil. Mnozí autoři začali s myšlenkou sociálního konstruktivismu dále pracovat, nelze ale hovořit o jedné jednotné pozici sociálního konstruktivismu (Stam, 2001).

4 Hlubší vhled do problematiky konstrukce sociální reality v podání Bergera s Luckmannem, kteří diskutují aktivní roli sociálního aktéra v konstrukci sociální reality a zároveň zohledňují také vliv sociálních struktur, je možné získat v autorčině studii Sociologie vědění jako cesta k promýšlení sociálních praktik (Kolaříková, 2018). 
a socializace ${ }^{5}$ dítěte, které je do dané konstrukce světa a s ní pojícího se rolového očekávání zasvěcováno především skrze jazyk, gesta a mimiku (tzv. komunální diskurz), skrze které jsou sociálním aktérům předávána konkrétní vyjádření jedince (tzv. jazykové skripty) i převládající společenské postoje, mýty a vyprávění, jež jsou diskurzivně podmíněné a jejichž mocenské dopady na člověka a jeho jednání zůstávají sociálním aktérům často skryté, neuvědomělé (tzv. komunální mýty).

V oblasti edukace je sociální konstruktivismus dle Kaščáka (2002, s. 403) spojen především s pojetím učení jako sociokulturního procesu „vytváření (jazykových) významů“, v rámci kterého jsou v daném sociokulturním prostředí za cílem udržení sociální koheze a konformity neustále reprodukovány ve společnosti dominující kulturní vzorce a komunální mýty, ${ }^{6}$ které mohou reprezentovat a konstruovat mimo jiné právě muzea. $V$ edukačním procesu jsou pak v optice sociálního konstruktivismu žáci vystaveni formativním mocenským praktikám a zájmům sociálního systému, který učitel zastupuje a pomocí jazyka i dalších prostředků reprodukuje (nebot' on sám byl do něj již dř́ve socializován) a jehož cílem je socializace žáků do konformních způsobů jednání a myšlení, které jsou v souladu s převládajícím diskurzivním pojetím světa a jeho fungování. Takový model edukace se přitom netýká jen prostředí školy, ale také muzea, které svým návštěvníkům představy o světě a realitě zprostředkovává.

Vedle sociálního konstruktivismu se ve svém textu Kaščák (2002) zabývá také konstruktivismem radikálním, ke kterému přidává přívlastek „individuální“. Na rozdíl od pojetí sociální reality Bergera s Luckmannem tento proud spíše odpovídá Kellyho teorii osobních konstruktů a je ve svém zájmu orientován spíše na procesy intrapsychické než interpsychické. Radikální konstruktivismus je více zaměřen na jedince a jím konstruovaný proces poznání, a to z pozice neurověd. Klíčovou je pro proces pochopení sociální reality osobnost sociálního aktéra, který sociální realitu konstruuje právě skrze poznávací činnost, což znamená, že zkonstruovaná skutečnost je výsledkem jeho vědomí, výsledkem činnosti mozku (Kaščák, 2002, s. 388-389). Mozek konstruuje sociální realitu individuálně, a proto nelze očekávat, že lze pomocí jedné stejné metodiky či metody naučit všechny žáky ve třídě naprosto stejným věcem.

5 Ostatně i Berger s Luckmannem (1999) označují proces socializace za klíčový a ve svém díle mu věnují velkou pozornost.

6 Povšimněme si podobnosti s procesem „legitimizace“, který je dle Bergera s Luckmannem (1999) důležitou součástí procesu socializace a skrze který je předáváno stávající sdílené vědění a pojetí světa dalším generacím jako vědění objektivně platné a samozřejmé. 
Znalosti jsou konstruovány individuálně a hlavní roli v jejich konstrukci hraje žák, nikoli učitel. Učitelovo úsilí má z pozice radikálního konstruktivismu směřovat především k ovlivnění kontextu učebního procesu. Učitel stojí před úkolem „respektovat kognitivní sebereferencialitu žáků a chápat učení jako autonomní a individualizovaný rozvoj kognitivních funkcí" (Kaščák, 2002, s. 394). Úlohou učitele je podílet se na aranžování učebního procesu, přičemž aranžování zahrnuje „návrh a zabezpečení vhodných situací a podmínek pro učení“ (Kaščák, 2002, s. 394) a na tzv. animování, což je „snaha (především motivačně) přispět $\mathrm{k}$ tomu, aby žáci tyto učební šance navozené aranžováním plně využili“ (Kaščák, 2002, s. 394).

V pojetí učícího se jedince jako aktivního aktéra, který se sám skrze své kognitivní procesy podílí na konstrukci znalostí i pojetí světa, je pak i tento typ konstruktivismu konstruktivistickým teoriím učení využívaným $\mathrm{v}$ muzeu velmi blízký. Jak ale správně Kaščák (2002) podotýká, je užitečné hledat cestu mezi oběma těmito směry, tedy mezi konstruktivismem sociálním i radikálním, nebot' využití poznatků z nich obou může přispět k zefektivnění edukační reality. Naopak uzavření se jen v jedné z nabízených teoretických rovin může být omezující. Předkládaná studie se proto snaží čerpat poznání z obou konstruktivistických směrů, které se dle mého přesvědčení v konstruktivistických teoriích učení vzájemně prolínají. Studie přitom předpokládá, že striktní orientace na konstruktivismus radikální by mohla vést k opomíjení socio-kulturní roviny vzdělávacího procesu. Naopak nevzít v potaz myšlenky radikálního konstruktivismu při strohé orientaci na konstruktivismus sociální by mohlo znamenat, že si uvědomíme sociální aspekt procesu konstrukce poznání, ale nedostatečnou pozornost budeme věnovat faktu, že poznání je individuálním procesem nejen z hlediska specifického socio-kulturního kontextu života a zkušenosti učícího se jedince, ale také $\mathrm{z}$ hlediska funkce jeho mozku, respektive jeho kognice.

$\mathrm{V}$ oblasti pedagogiky se konstruktivismus nejviditelněji projevuje $\mathrm{v}$ konstruktivistických teoriích učení, které z něj vycházejí. Konstruktivistické teorie učení si uvědomují fakt subjektivní reality, respektive subjektivity světa, vědění a myšlení a s tím pojící se kontext nejen vědění a jednání, ale i celého procesu učení, osvojování si informací a jejich interpretace. Při využití konstruktivismu v pedagogice se proto zájem obrací především k vlivu učících se jedinců na jejich učební proces, který je vedle dalších faktorů (prostředí, obsah učiva, role pedagoga apod.) ovlivněn právě jejich osobními charakteristikami a kognitivními schopnostmi (viz konstruktivismus 
radikální), socio-kulturním kontextem jejich života, stejně jako jejich dosavadními znalostmi a životními zkušenostmi. Socio-kulturní podmíněnost vzdělávacího procesu (tedy společnost a kultura, ve které učící se jedinec žije, lokalita, ve které vyrůstá, sociální vztahy, které má a které formují jeho osobnost, názory i chování) je nezanedbatelná a také v ní se (sociální) konstruktivismus odráží.

\section{Konstruktivismus v pedagogice: konstruktivistické teorie učení}

V rámci pedagogických věd lze konstruktivismus chápat bud' epistemologicky jako teorii o poznání, nebo jako formu pedagogiky, která indikuje typy výukových teorií (Kwan \& Wong, 2015). V obou př́ípadech se tato pojetí zakládají na stejných myšlenkách, které se odrážejí v tzv. konstruktivistických teoriích učení. Ty mimo sociální konstruktivismus navazují na myšlenky pedagogických klasiků, jakými jsou Dewey s jeho pragmatickou pedagogikou, Vygotsky či Piaget, a spolu s působením konstruktivistického paradigmatu sociálních věd formují nové pedagogické paradigma.

Konstruktivistické teorie učení se vymezují proti klasickým teoriím učení (srov. Siebert, 2006; Taber, 2011; Vollmers, 1997), které předpokládaly, že učící se jedinec přichází ke znalosti skrze rozpoznání skrytého, apriorního, ale zároveň rozpoznatelného smyslu vyskytujícího se v jeho prostředí. Klasický přístup chápal učební proces jako děj, ve kterém učitel sděluje znalosti žákům, které se do nich otisknou ve stejné podobě, $v$ jaké je učitel předkládá. Vzhledem k tomu se klasická škola zaměřovala nebo stále zaměřuje především na frontální výklad, a vytváří tak pasivní učební prostř̌edí založené na memorování poznatků spíše než na pochopení předkládaných informací. Žáci si sice osvojují velké množství učiva, ale toto učivo často neumí v praxi použít. Edukační proces i učivo bývají odtrženy od každodenního života žáků i od jejich vlastní zkušenosti. I proto klasická škola podle Piageta (cit. podle Vollmers, 1997) žáky k učení dostatečně nemotivuje a nestimuluje, naopak přirozený zájem dítěte utlumuje. Spontánní činnost žáka a jeho přirozený zájem jsou přitom podle Piageta pro edukační proces klíčové. Podle Piageta (cit. podle Vollmers, 1997) má být žákovi ponechána naprostá svoboda v rozvíjení vlastních vzdělávacích aktivit. Řídit proces učení podle něj není nutné. Přirozený zájem dítěte zaručuje učební úspěch. Piagetovi kritici však jeho vizi přirozeně aktivního, zvědavého, motivovaného a schopného žáka 
odmítají jako naivní a nerealistickou. Není se čemu divit. Předpokládat, že všichni žáci budou dokonale zvídaví, by bylo stejně zjednodušující a nepřesné jako tvrdit, že si všichni žáci v edukačním procesu osvojí stejné znalosti.

Konstruktivistické teorie učení upozorňují, že nic jako univerzální proces učení s výslednými univerzálně osvojenými informacemi a znalostmi neexistuje. Znalost je dle konstruktivistů rozvíjena v interaktivním procesu a pomalu budována skrze životní zkušenosti. Zažívané zkušenosti a informace opíráme o již existující kognitivní zdroje (znalosti, postoje, interpretační rámce apod.) na jejichž základě získávaná data vyhodnocujeme, interpretujeme a aktivně vytváříme vlastní významy, které okolním jevům a informacím přisuzujeme (Taber, 2011). To je přitom v souladu s pojetím sociální reality konstruktivistických teorií, které tvrdí, že „v každodenním životě naše mysl asimiluje a přetváří nové informace tak, aby byly $\mathrm{v}$ souladu $\mathrm{s}$ našimi dosavadními znalostmi a dříve vytvořenými schématy (tj. aby ,dávaly smy$\mathrm{sl}^{\prime} \mathrm{z}$ hlediska toho, co už o světě víme), a zároveň naše mentální informační struktury přizpůsobujeme nebo měníme tak, aby odrážely to, co jsme se z nové zkušenosti naučili.“ (Pasch et al., 1998, s. 147).

Lidská mysl tedy neustále konstruuje smysl toho, co jedince obklopuje, ve snaze okolní realitě porozumět a přiměřeně na ni reagovat. A obdobně i v Deweyho pragmatismu „poznání neznamená kopírování světa, ale artikulaci světa takovým způsobem, abychom věděli, jak náležitě jednat" (Šíp, 2015, s. 680). Cílem poznání není odhalit objektivní pravdu, nýbrž zorientovat se v dané situaci a přizpůsobit jí své jednání. Poznání je dle konstruktivismu subjektivní záležitostí. Vědomost je vždy individuální a aktivně utvářená konkrétním jedincem. Lidé (at' už žáci ve škole nebo návštěvníci muzea) si osvojují dané věci $v$ jiné podobě, než $v$ jaké to bylo pedagogem zamýšleno. Každý učící se jedinec si utvoří vlastní osobní verzi toho, co bylo školou či muzeem zprostředkováno. Výsledný edukační efekt se může lišit nejen od toho, co zamýšlel pedagog, ale i od toho, co si z učebního procesu odnesli spolužáci. Pedagog nemůže očekávat, že si všichni žáci či návštěvníci muzea osvojí a z edukace odnesou stejné znalosti a dojmy (srov. Hein, 1995, 1999, 2001).

V rámci teorie konstruktivismu je patrná neoddělitelnost poznání od každodenního života a každodenní zkušenosti jedince. Poznání člověka je vždy kontextuální, nebot' je spojeno nejen s ním samotným, ale také s jeho prostředím - oba tyto faktory tvoří neoddělitelný celek procesu poznávání, učení a celé žité zkušenosti, respektive situace, v níž se jedinec nachází a kterou Šíp (2015, s. 681) v rámci Deweyova odkazu popisuje jako „naprostou 
provázanost jednajícího se svým okolím.“ Tento aspekt se přitom odráží také v procesu učení, který má být dle konstruktivistických teorií učení založen na osobní životní zkušenosti a znalosti učících se jedinců. Podle Deweyho (1997) pragmatické edukace je edukace vystavěna právě na doposud vybudovaných znalostech ${ }^{7}$ a dovednostech učících se jedinců. Tyto znalosti jsou v procesu probíhající edukace transformovány do znalostí nových.

Průběh edukačního procesu ovlivňují i další vlivy, výrazně pak osobnostní charakteristiky učících se jedinců, kam spadají nejen jejich schopnosti, ale také motivovanost $\mathrm{k}$ učení, aktuální stav pozornosti, momentální emoční ladění, kognitivní a metakognitivní strategie (strategie myšlení a učení) ${ }^{8}$, socio-kulturní, genetické a fyzické charakteristiky a podobně. Svou roli sehrává i samotný proces učení, jeho obsah i podmínky, kam se řadí například fyzické prostředí, výukové materiály, role pedagoga a celý kontext učebního procesu, který se zakládá nejen na dřívějších zkušenostech, ale také na zkušenosti aktuálně prožívané. Tyto zkušenosti se přitom netýkají jen samotné učební látky či muzejní expozice, ale souvisejí s architekturou tř́dy či muzea a komfortem, který muzeum svým návštěvníkům nabízí či nenabízí (toalety, občerstvení, prostor k sezení apod.), se zážitky spojenými s cestou do muzea, se vstupným a celkově i s tím, o jaký typ muzea se jedná - zda jde o muzeum národní, technické a podobně (srov. Falk, Dierking, \& Adams, 2006; Hein, 1995, 1999, 2001; Taber, 2011).

Fakt, že musíme brát v potaz celý vzdělávací kontext, naznačuje, že svou roli sehrává i učitel či pracovník muzea (v ideálním případě muzejní pedagog), který se na edukačním procesu podílí, a nelze jej proto vyčlenit z kontextu edukačního procesu. Byt' je učící se jedinec v centru pozornosti konstruktivistických teorií učení, zanedbána není ani rovina ostatních vlivů, které na něj ve škole či v muzeu působí, čímž se do jisté míry (především pak v rámci muzejní edukace) mírní kritika směřována vůči konstruktivistickým teoriím učení, kterým je dle Průchy (2002, s. 77) vyčítáno to, že podceňují roli učitele. Především z pozice sociálního konstruktivismu je ale pedagog a jeho role neoddělitelnou součástí edukačního procesu. Je to totiž právě pedagog, kdo se podílí na reprodukci dominantních společenských diskurzů, které vědomě či

\footnotetext{
Pojetí zkušenosti a její rolí v edukačním procesu se bude hlouběji věnovat další kapitola textu.

8 V rámci metakognice se jedná o způsob myšlení a zpracovávání informací zahrnující proces zapamatovávání, způsob transformace informací ve znalosti, vybavování si poznatků a jejich používání i následné vyhodnocování a reflektování (Kwan \& Wong, 2015, s. 71).
} 
nevědomě učícím se jedincům zprostředkovává a ovlivňuje tak celý edukační proces. Zároveň je to učitel, který se podílí na pedagogizaci prostředí. V neposlední řadě pedagog ovlivňuje edukaci skrze její didaktické směřování, respektive skrze promýšlené didaktické vystavění celého edukačního procesu, které je důležité nejen v konstruktivistickém, ale $\mathrm{v}$ jakkoli pojatém edukačním procesu. Jak totiž upozorňuje Štech $(2003$, s. 84), „ani u toho nejnadanějšího žáka není proces učení individuálním aktem. Vždy musí být př́ítomný druhý člověk, který artefakty kultury oživí, ukáže způsoby zacházení s nimi, uvede novice do jejich zvládání." $V$ rámci muzejní edukace je tímto člověkem muzejní pedagog, který by měl v kontextu vize konstruktivismu „předávat poznatky takovým způsobem, aby si je žáci mohli sami zkonstruovat" (Štech, 2003, s. 68). Tedy tak, aby nové poznání učící se jedinci aktivně stavěli na svých dosavadních znalostech a prekonceptech a skrze aktivní proces osvojování si poznatků si postupně uvědomovali jejich př́ipadnou neúplnost, nepřesnost či chybnost a transformovali je do konceptů nových, přesnějších (resp. aby konstruovali nové poznání). Aktivní role návštěvníků muzea je zde jasná, jasná by měla být ale i důležitost role pedagoga, který v muzeu vybírá nejvhodnější artefakty, které budou do muzejní edukace zapojeny (a na jejichž interpretaci se podílí), a spolu s tím promýšlí a plánuje aktivity s nimi spojené tak, aby byl jejich didaktický efekt co největší.

Druhým bodem kritiky konstruktivistických teorií učení bývá možné zanedbávání významu předávaných znalostí. Podle Sieberta (2006) ale v konstruktivistické pedagogice nejde o to, že by si neuvědomovala důležitost odborných znalostí. Ty vnímá jako potřebné. Pouze zdůrazňuje, že člověk má být do procesu jejich získávání aktivně zapojen, má rozvíjet své edukační dovednosti (především dovednost učit se) a má za svou edukaci a její proces přijmout vlastní zodpovědnost. Hlavním cílem konstruktivisticky pojaté edukace je pomoci učícím se jedincům osvojit si způsoby získávání poznatků, s čímž souhlasí i Štech (2003, s. 68), podle kterého „dovednosti získat, použít a tvořit nové poznatky jsou dnes považovány za stejně významné jako objem osvojených poznatků. Jde tedy o nový důraz, který nám ř́ká: nejlépe si osvojíme poznatek tak, že se s ním naučíme i postupy, jak se vypracovává (elaboruje)." Tedy nejen poznatky samotné jsou důležité, ale právě proces jejich získávání stojí v centru pozornosti konstruktivisticky orientované edukace, která se snaží tento proces nejen zefektivnit, ale také pro učící se jedince zvědomnit a spolu s tím budovat a posilovat schopnosti jedinců informace a znalosti vyhledávat, získávat a vyhodnocovat. Jedná se o dovednosti, 
které se muzejní edukace může snažit rozvíjet, aniž by přitom znevažovala významnost znalostí samotných. Znalosti jako takové jsou samozřejmou součástí muzejní edukace, nebot' ta je již ze své podstaty založena na expozici a muzejních objektech, a tedy i na s nimi pojících se odborných znalostech, které jsou ve spojitosti s muzeáliemi přirozenou součástí muzea a měly by být také přirozenou součástí muzejní edukace.

Jestliže je v rámci konstruktivistických teorií učení učící se jedinec vnímán jako jedinec aktivně se podílející na procesu učení, který své učení staví na dosavadních znalostech a zkušenostech a který aktivně produkuje nové jedinečné znalosti, pak je cílem zastánců těchto teorií vytvořit takové učební prostředí, které podporuje proces aktivního učení se člověka. Snaha směřuje k vytvoření tzv. konstruktivistického učebního prostredí, které si uvědomuje význam dosavadních znalostí a zkušeností jedinců v učebním procesu a ve kterém je vytvářen prostor pro rozvoj a podporu kritického myšlení. Kritické myšlení je jedním z klíčových pojmů, na který se konstruktivistické teorie učení orientují. Kritické myšlení Kwanová a Wongová (2015, s. 69) chápou jako přiměřené reflektivní myšlení zaměřené na rozhodování o tom, čemu věřit a co dělat. Formováno pak může být především skrze podporu používání správných kognitivních procesů, ${ }^{9}$ které se na myšlení jedinců podílejí. Bez posilování kognitivních a metakognitivních ${ }^{10}$ strategií dle Kwanové

9 Nesprávně používané kognitivní strategie naopak k rozvoji kritického myšlení dle Kwanové a Wongové (2015) vést nemusejí, naopak jej mohou brzdit. A to např. ve chvíli, kdy je získaná informace špatně pochopena a následně chybně používána apod. Cílem konstruktivistických teorií učení proto dle autorů má být naučit učící se jedince využívat kognitivní a metakognitivní strategie správně, uvědoměle a efektivně. S tím souhlasí i Taberová (2011) která zdůrazňuje, že učební proces se má pokoušet především o aktivizaci relevantních myšlenek žáků, které již mají k dispozici, za cílem pomoci jim konstruovat nové znalosti, propojovat dosavadní informace s novými a navazovat na ně.

10 Pojem metakognice vysvětluje Hacker (cit. podle Lokajíčková, 2014, s. 288) jako „znalost poznání, monitorování a řízení kognitivních aktivit“. Metakognice je znalostí vlastních kognitivních procesů a uvědomění si jich samotných i jejich výsledků. Jde tedy o schopnost člověka uvědomit si vlastní proces myšlení a porozumění a aktivně jej monitorovat a regulovat. $S$ tím se pojí schopnost jedinců usoudit, zda je jejich poznání dostatečné, nebo je nutné je prohloubit, k čemuž dochází v rámci edukačního procesu. Součástí metakognice je tak i schopnost plánování a regulace vlastního učení, snaha o aktivní zapojení se do procesu učení a schopnost vyhodnocení jeho výsledků (tamtéž). Schopnost metakognice se přitom začíná vyvíjet u dětí starých pět až sedm let a na rozvoji jejich metaakognitivních schopností se může podílet učitel. K tomu je zapotřebí, aby učitel znal dosavadní znalosti dětí, podněcoval jejich myšlení prostřednictvím dotazování, vedl je k aktivnímu zapojení se do učebního procesu, výsledky učebního procesu s žáky rekapituloval apod. (Lokajíčková, 2014, s. 295-297). 
a Wongové (2015) nemůže být rozvoj kritického myšlení nikdy zcela úspěšný. Žáci proto mají být vedeni k jejich záměrnému používání. V praxi to znamená, že jsou jedinci motivováni k porovnávání nových informací s těmi dosavadními, na základě čehož mají dospět k aktivnímu porozumění i vrstvení nových informací. Zároveň jsou vedeni k diskuzi, v níž se učí argumentovat, tříbit své názory a díky zpětné vazbě zvažovat svá dosavadní stanoviska. Cílem konstruktivistického učení je podporovat schopnost kritického myšlení ve smyslu uvažování a usuzování, porozumění a pochopení, využívání znalostí, hloubkového a nikoli, jen povrchového zpracování problému, samoregulace a vědomé reflexe.

Z důrazu kladeného různými autory na rozvoj kritického myšlení žáků je patrné, že nejen rozvoj znalostí je v současném edukačním diskurzu považován za důležitý. $V$ dnešní proměnlivé společnosti nejde pouze o to informace získávat, ale také umět je vyhodnocovat a kriticky zvažovat. Pozornost je proto věnována rozvoji dovedností reflexe a interpretace složitých a různorodých informací. Edukace má napomáhat tomu, aby byl jedinec schopný informace získávat, trrídit, integrovat, analyzovat i sdílet. K tomu je podle Scheerové, Noweskiové a Meinela (2012) potřeba, aby byl edukační proces zaměřen nejen na obsah vzdělávání, ale právě na rozvoj metakognitivních kompetencí, postojů, hodnot a akčních dovedností. Ty totiž napomáhají efektivně internalizovat znalosti. Aby byli lidé schopni řešit komplexní problémy svého každodenního života, podle autorů je důležité, aby měli osvojené klíčové kompetence potřebné $\mathrm{k}$ jejich řešení. Konkrétně se podle Wagnera (cit. podle Scheer et al., 2012, s. 9) jedná o sedm základních kompetencí, kterými jsou nejen 1) schopnost kritického myšlení a řešení problémů, ale také 2) pružnost a přizpůsobivost; 3) iniciativa a podnikavost; 4) zvídavost a představivost; 5) efektivní ústní i písemná komunikace; 6) schopnost obstarat si př́stup k informacím a 7) následně je analyzovat a zároveň i sdílet v rámci širokých sociálních sítí.

Takzvaných klíčových kompetencí je ale daleko více a jejich problematika je dnes odborníky často diskutována. Zájem studie o klíčové kompetence přitom vychází ze dvou základních premis. Zaprvé jsou klíčové kompetence úzce navázány na konstruktivistické teorie učení, se kterými sdílí vizi rozvoje určitých pro dnešního člověka důležitých kompetencí (napřs. schopnost kritického myšlení). Zadruhé se v praxi muzejní edukace s klíčovými kompetencemi v České republice poměrně často setkáváme. Muzejní pedagogové, jak 
si dále ukážeme, na ně totiž ve svých edukačních programech a jejich popisech předkládaných potenciálním klientům často odkazují. Je proto vhodné nyní poskytnout alespoň základní vhled do dané problematiky, která bude odpovídat kontextu dané studie. Zaměříme se přitom nejen na objasnění pojmu klíčových kompetencí a jejich zasazení do problematiky spjaté s konstruktivismem, ale také uvedeme rovinu jejich možné kritiky, respektive nastíníme sporné body, které by měli muzejní pedagogové pracující s klíčovými kompetencemi znát.

V českém prostředí se $\mathrm{s}$ klíčovými kompetencemi běžně setkáváme v rámcových vzdělávacích programech a školních vzdělávacích programech. Dle Rámcového vzdělávacího programu pro základní vzdělávání (MŠMT, 2005, s. 6; dále jen RVP)

klíčové kompetence představují souhrn vědomostí, dovedností, schopností, postojủ a hodnot důležitých pro osobní rozvoj a uplatnění každého člena společnosti. Jejich výběr a pojetí vychází z hodnot obecně přijímaných ve společnosti a z obecně sdílených představ o tom, které kompetence jedince přispívají k jeho vzdělávání, spokojenému a úspěšnému životu a k posilování funkcí občanské společnosti.

Mezi základní klíčové kompetence, k jejichž utváření a rozvíjení mají přispívat veškeré školní aktivity i vzdělávací obsah, pak RVP (MŠMT, 2005, s. 6-9) řadí kompetence k učení (např. schopnost samoregulace učení ${ }^{11}$, vyhledávání a třídění informací i jejich využití v životě), kompetence $\mathrm{k}$ řešení problémů (napřr. schopnost problém rozpoznat, pochopit i řešit, kriticky myslet), kompetence komunikativní (např. schopnost se smysluplně vyjadřovat i naslouchat, diskutovat), kompetence sociální a personální (např. schopnost spolupracovat ve skupině, respektovat cizí názor), kompetence občanské

11 Samoregulace procesu učení je typickým požadavkem konstruktivistických teorií učení. Realizace tohoto požadavku ale může být problematická. Člověk má v rámci jeho požadavků např. možnost pracovat svým vlastním tempem, stanovovat si vlastní cíle, má si být vědom vlastních znalostí, má přijímat vlastní rozhodnutí apod. Jak ale upozorňují Wilde a Urhahne (2008), tyto nároky kladené na učící se jedince jsou náročné a vyžadují od nich určitou disciplínu. U méně nadaných žáků může vést takto postavená edukace $\mathrm{k}$ dezorientaci a špatným výsledkům učení. Možností, jak se vyvarovat těchto negativních dopadů, pak podle autorů je využít tzv. umírněný konstruktivismus, který propojuje prvky konstruktivismu s určitou mírou kladení instrukcí a strukturace edukačního procesu. Pro umírněné konstruktivisty samoregulace znamená mít možnost volby a kontroly. Poskytování volby zde nahrazuje odměny a tresty, přičemž zastánci tohoto přístupu předpokládají, že pocit autonomie bude učícím se jedincům přinášet pocit uspokojení a spolu s tím bude zvyšovat jejich motivaci k učení. Ve vlastním výzkumném šetření však tuto hypotézu autoři nepotvrdili. 
(např. vědomí o vlastních právech a povinnostech), kompetence pracovní (např. schopnost adaptace na nové pracovní podmínky).

Klíčové kompetence se v minulosti staly součástí kurikulární reformy a vize současného vzdělávání ve světě i u nás. Jejich rozmach dle Štecha (2013) vytvořil iluzi odpovědi vzdělávacího systému na současné potřeby pozdně moderní společnosti a v ní probíhající edukace. Kritika klíčových kompetencí vychází nejen z upozornění na vágnost a nejasnost jejich definic. Problematické je podle Štecha (2013) to, že zavedení klíčových kompetencí vychází z neoliberálního, na profesní dráhu orientovaného diskurzu, který nově pojmenovává již dříve diskutované problémy, mezi které patří především kritika klasické školy. Tato kritika se původně objevovala $\mathrm{v}$ reformních proudech pedagogiky, kam spadá právě Dewey, a v různých podobách (dle Štecha právě i v rámci aktivizujících konstruktivistických proudů) se vyskytuje dodnes. Tyto proudy přitom často rétorikou kompetencí hovoří. Nekritická orientace vzdělávání na kompetence a generické schopnosti je ale podle autora problematická. Kompetence podle něj „představují jakousi ,konativní slitinu', kterou nelze vztáhnout k žádné specifické psychologické nebo pedagogické koncepci či teorii“ (Štech, 2013, s. 623). Bez fundovaného teoretického zázemí je ale obtížné pedagogy na vyučování zaměřené na kompetence připravovat.

Problematické je podle Štecha (2013) i zaměření kompetencí na moment mobilizace žákových kompetencí v nových situacích, které žák nezažívá, a tak si je nemůže ve výuce vyzkoušet a prožít. Přehlíží se podle něj fakt, že kompetence jakožto schopnost jednat není žádnou apriorní vlastností, nýbrž se prolíná s faktickými odbornými vědomostmi, jejich osvojením, procvičením, upevněním a zautomatizováním. Kompetence navíc nejsou univerzální a jejich podoba i kvalita (míra osvojení) se může u jednotlivých žáků lišit. Nelze proto předpokládat, že všichni žáci dosáhnou stejného stupně rozvoje daných kompetencí, ani že jsou všichni žáci předem stejně disponováni k jejich rozvoji - tak jak to podle Štecha (2013, s. 621) předpokládá „elitářský přístup ke kurikulu, který implicitně počítá s kognitivními i sociálně-afektivními předpoklady žáka $\mathrm{z}$ vyšší střední tř́́dy u všech žákư". Takto orientovaný přístup pak podle autora může vést spíše k posílení sociální nerovnosti než $\mathrm{k}$ její eliminaci. Považovat klíčové kompetence za neproblematické, nekriticky je přijímat a nereflektovaně se je snažit rozvíjet tak shledávám jako sporné. Nechci přitom tvrdit, že jsou klíčové kompetence nesmyslné. Naopak, v rámci ducha studie je vnímám jako žádoucí rozvoje. Upozornění ale směřuje $\mathrm{k}$ faktu, že stejně jako nelze očekávat, že se všichni učící jedinci 
v edukačním procesu naučí stejným znalostem, nelze očekávat ani to, že si stejnou měrou osvojí a rozvinou konkrétní klíčové kompetence.

Cílem textu není diskutovat postavení klíčových kompetencí ve vzdělávacím systému ani dalekosáhle zvažovat jejich klady a zápory. Přesto se zdá důležité na rovinu možné kritiky upozornit, protože jsou to právě klíčové kompetence, které jsou často spjaty s problematikou konstruktivistických teorií učení i s diskuzí současné muzejní edukace a jejího poslání. V podstatě je možné říci, že se kurikulární reforma dotkla nejen škol, ale i muzeí, jen do nich došla o něco později než do prostředí škol (ve světě pak dříve než u nás). Muzejní pedagogika je oborem, který nenavazuje pouze na muzeologii, ale také na pedagogiku, která realitu muzejní edukace svou podobou a aktuálními trendy ovlivňuje. Je to ale také orientace muzea a jeho edukační nabídky na prostředí škol, která sehrává výraznou roli v tom, že se v muzejní edukační nabídce dnes o klíčových kompetencích často dočteme. Ve snaze vytvořit lukrativní nabídku edukačních programů, které budou učitelé se svými žáky navštěvovat, totiž muzea včleňují do cílů svých programů právě rozvoj klíčových kompetencí. Dle Jagošové a kol. (2010, s. 243) muzeum „užívanými metodami a způsoby práce s dětmi v rámci programů a projektů zpravidla zcela samozřejmě přispívá k rozvíjení jak klíčových kompetenci, tak i vzdělávacích oblastí a průřezových témat." A ve chvíli, kdy tak muzeum koná cíleně a veřejně rozvoj klíčových kompetencí deklaruje, je dle autorů pro muzeum snazší se školami navázat spolupráci. Učitelé totiž často právě o takové programy projevují zájem.

Muzejní pedagog orientující se na rozvoj klíčových kompetencí by si ale měl uvědomit komplexnost této problematiky a do svých edukačních programů by je neměl zařazovat nahodile a nepromyšleně, jen ve snaze přilákat školní skupiny. Chce-li muzejní pedagog klíčové kompetence do edukace implementovat, může mu v tom pomoci právě znalost konstruktivistických teorií učení, a naopak i klíčové kompetence mohou být nápomocné při snaze aplikovat konstruktivistické prvky do edukace. Lze přitom předpokládat, že do prostředí muzea mohou být klíčové kompetence „překlopeny“ s menšími problémy než do prostředí školy, které je ve své činnosti více „omezeno“ a strukturováno daným kurikulem. Konkrétní klíčové kompetence, kterým je vyčítána jejich abstraktnost, navíc nebývají v muzeu součástí edukace jako abstraktní entity, ale $\mathrm{v}$ dobře provedeném edukačním programu nabývají konkrétní podobu a zrcadlí se v řadě úloh a aktivit, které si návštěvníci reálně 
zkoušejí a procvičují. Nejsou to ale jen klíčové kompetence, na které se konstruktivistické teorie učení zaměřují. Doménou konstruktivistických teorií učení je vize postupného budování znalostí a dovedností. V tom ostatně konstruktivismus sdílí názor s kognitivisty, kteří dle Štecha (2013, s. 628) kladou „důraz na struktury uspořádání poznatků“, respektive vědomostí; tj. na fakt, že schopnost řešení problémů je vystavěna na dřivějších znalostech i zkušenostech žáka. Takto pojatá konstruktivistická edukace pak není s požadavky kognitivistů v rozporu, nýbrž s nimi jde ruku v ruce, byt' sám Štech je staví do opozice a názory kognitivistů v kritice problematiky klíčových kompetencí argumentačně využívá.

I přes možné výtky směřující ke konstruktivistickým teoriím učení může být pro edukační proces př́nosné vycházet vstříc jejich požadavkům. Pro pedagogy se ale jedná o nelehký úkol. Nejde jen o vágnost pojmu kompetence nebo o náročnost konstruktivisticky orientovaných edukačních aktivit (náročnost jejich přípravy i koordinace). Podle Scheerové a kol. (2012) tkví problém v neexistenci širší základny efektivních doporučení, která by již, kteří jsou v rámci konstruktivismu chápáni jako facilitátoři a průvodci edukačního procesu, radila, jak konkrétně konstruktivistické prvky zapojit v praxi. Určité obecné strategie přitom mohou, i přes svou diskutabilitu, nabídnout právě teorie zabývající se rozvojem klíčových kompetencí. V praxi jde při získávání klíčových kompetencí o to, aby byli žáci do procesu edukace plně zapojeni, aktivně na ní participovali, měli možnost si učební látku v praxi vyzkoušet, aktivně přemýšlet a byli schopni obecné a abstraktní jevy převést a aplikovat do reálné praxe v podobě smysluplného jednání. Myšlení a jednání je totiž neoddělitelně propojeno a obojí má být zapojeno do edukačního procesu. V Deweyho pojetí se tento fakt projevuje v tzv. metodě konstruktivního řešení problému (cit. podle Scheer et al., 2012, s. 11). Tato metoda se soustřed'uje na motivování učícího se jedince $\mathrm{k}$ analýze a následnému řešení předkládaného problému. Jde o propojení myšlení a jednání v praxi. Analýza problému se odehrává na základě dosavadních znalostí, které jsou následně obohacené o novou zkušenost, a vyhodnocení řešené situace. ${ }^{12}$

2 Stejně jako Deweyho metoda kladou důraz na učení se prostřednictvím zkušenosti a komplexního řešení problémů i metody zabývající se rozvojem klíčových kompetencí. Jako příklad uved'me tzv. design thinking, tedy jakési designové myšlení (Scheer, Noweski, \& Meinel, 2012, s. 11-13), v jehož rámci jsou jedinci vedeni k aktivnímu promýšlení jevů, k vyjadřování vlastních názorů a jejich sdílení s ostatními. Proces metody se zakládá na několika fázích. Prvním krokem je zkoumání daného jevu, snaha porozumět mu. Druhým krokem je syntéza, během které dochází k interpretování a kritickému zhodnocování získaných informací. 
Také cílem konstruktivistického stylu učení je navazovat na dřívější znalosti učících se jedinců, rozvíjet je, pomáhat žákům nové informace třídit a celkově jedince učebním procesem provázet ve snaze jim učební proces nejen ulehčit, ale také maximalizovat jeho efekt. Dle Zormanové (2012, s. 12) se tak děje především prostřednictvím snahy aktivizovat učící se jedince a jejich poznávací procesy, dále skrze podporu samostatné práce, rozvoje představivosti, logického myšlení a tvůrčích schopností osobnosti. Logicky se pak tento učební styl pojí s metodou dialogu, diskuze, brainstormingu, didaktické hry, inscenační a situační metody, projektové výuky, skupinové a kooperativní výuky a podobně.

\section{$4 \quad$ Aplikace konstruktivistických teorií učení do prostředí muzea}

Využití konstruktivistických teorií učení není omezeno jen na prostředí školy, nýbrž je mu čím dál více pozornosti věnováno také v jiných institucích, především muzeích. Mimo svou roli v informálním učení mohou muzea sehrávat úlohu také v kontextu spolupráce se školou. Muzea mohou být využívána nejen za cílem obohacení výuky v rámci školního kurikula, ale také k celkovému rozvoji osobnosti žáků. Právě využití kultury pro edukaci a kutlivaci návštěvníků je dominantou muzejního prostředí. K rozvoji nejen jedincových znalostí a dovedností, ale také názorů, postojů, schopností, způsobů chování a k rozvoji osobnosti jako takové pak mohou být v muzejněedukačním procesu využívány právě konstruktivistické teorie učení. Ty se v rámci prostředí muzea jeví jako ideálně-typický model edukačních strategií i cílů, o jehož naplnění se muzeu může vyplatit usilovat.

Významnou osobností zabývající se konstruktivistickými teoriemi učení v rámci muzea je George E. Hein, který jako jeden z mála autorů podává

Následuje fáze představivosti, $\mathrm{v}$ rámci které jedinec hledá nápady směřující $\mathrm{k}$ řešení problému. Další fází je konsolidace, ve které jde o snahu přenést do té doby abstraktní nápady do praxe. Následuje fáze testování, v jejímž průběhu se generuje a v praxi zkoušejí možná řešení. Cyklus je uzavřený zpětnou vazbou. Obdobně je i dle de Corteho (2012, s. 35-36) pro edukaci zaměřenou na rozvoj klíčových kompetencí podstatné, aby byla aktivně utvářena učícími se jedinci a vystavěna na jejich dřivějších znalostech, které jsou v aktuálním učebním procesu nově reorganizovány. Edukace má být situovaná v sociálním, kulturním a situačním kontextu, tzn. má se dotýkat každodenního života jedince, má být založená na vzájemné spolupráci a sociální interakci a v neposlední řadě by měla být samoregulovaná učícím se jedincem. Podobnost takto zaměřené edukace s požadavky konstruktivistických teorií učení je nepřehlédnutelná. 
ucelené pojetí problematiky konstruktivistických teorií učení využívaných v muzejní edukaci. Hein úzce čerpá z Deweyho, což se projevuje už v samotném pojetí muzea jako významné edukační instituce zapojené do chodu demokratické společnosti. Inspirace Deweym je zřetelná také v užívání pojmu muzejní zkušenosti i důrazu na aktivní přístup návštěvníků k expozici, který se projevuje v rovině aktivního konstruování významů i v praktické manipulaci s předměty. Už Dewey ${ }^{13}$ (cit. podle Hein, 2004, s. 413) totiž prosazoval myšlenku, že ideje jsou neúplné, dokud se neaplikují do reálných situací, v nichž jsou zkoušeny a postupně osvojovány a modifikovány pro další použití v nových a obdobných situacích.

Ve svých dílech Hein hovoří o tzv. konstruktivistickém muzeu ${ }^{14}$. V tomto pojmu zohledňuje cíle a vizi moderního muzea, které se typicky orientuje na své publikum a jeho potřeby. Konstruktivistické muzeum je podle Heina (1995b) to muzeum, které si uvědomuje, že divák v průběhu návštěvy pod vlivem expozice a exponátů konstruuje vlastní znalosti a proces získávání znalostí je sám o sobě konstruktivním činem. Takovéto muzeum pak podporuje proces tvorby vlastních významů návštěvníka tak, že se snaží expozici navrhnout

13 Dewey sám o sobě nereprezentuje konstruktivistické paradigma, nýbrž pragmatickou pedagogiku, která s konstruktivismem sdílí některé společné body zájmu, a proto se pro konstruktivistické teorie učení stala zdrojem inspirace (vedle dalších inspiračních zdrojů o kterých již byla řeč). Pragmatická pedagogika se ustavila na přelomu 19. a 20. stol. v USA a jejím hlavním představitelem byl právě Dewey. Tento pedagogický směr se již od svého počátku hlásil k tomu, že chce pomocí výchovy napomoci k řešení problémů tehdejší společnosti, která se potýkala se společenskými změnami způsobenými modernizačními procesy. Za cílem vyrovnat se s nastalými společenskými proměnami zaváděla pragmatická pedagogika řadu pedagogických inovací, často spjatými s demokratickými ideály, kterými se vymezovala proti do té doby ve výchovné praxi převládajícímu herbartismu. Základní myšlenkovou osu u Deweyho tvořila vize myšlení jako prostředku, kterým může člověk vyhodnocovat svou situaci a hledat její správné řešení. K nalezení správného řešení přitom vede osobní jednání, tj. subjektivní praktická činnost, vlastní zkušenost. Právě zkušenost se pak stává klíčovým konceptem pragmatické pedagogiky, která razí heslo „, learning by doing“, tedy učení činností (Singule, 1991). Do oblasti konstruktivistických teorií učení pak pragmatismus, jmenovitě Dewey, řadí Hein, který je ve svém odborném působení Deweym velmi ovlivněn a k jeho odkazu se otevřeně hlásí. A jelikož je Hein světově uznávaným odborníkem a zároveň jedním z mála autorů, který přináší ucelené pojetí konstruktivistických teorií učení využívaných v prostředí muzea, stává se i Dewey autorem, $\mathrm{k}$ jehož práci se autoři věnující se problematice konstruktivismu v muzeích obracejí.

14 Tento pojem $\mathrm{v}$ předkládané studii chápejme spíše z Weberovy perspektivy jako jakýsi ideálně-typický pojem než jako reálně existující model muzea, tedy spíše jako ideální podobu muzea, které by se moderní muzea měla pokoušet přiblí̌zit ve snaze zefektivnit svůj edukační a sociální potenciál. 
jako prostor bohatý na významy a př́iběhy, na jejichž základě si sám návštěvník může vyvodit pointu a vlastní názor na předkládané jevy. Celková pozornost muzea je zde věnována především návštěvníkovi, tj. učícímu se jedinci a jeho potřebám, nikoli samotnému obsahu ${ }^{15}$, tedy tomu, co se má návštěvník v muzeu naučit. Proto je pro konstruktivistické muzeum dle Heina (cit. podle Jůva, 2004, s. 128) typické, že se snaží maximalizovat možnosti učení návštěvníků tím, že bere v potaz jejich dispozice a vývojové zvláštnosti a snaží se pracovat se všemi věkovými skupinami i místními komunitami, na něž zaměřuje svou činnost a pro které se snaží být přitažlivým a důležitým místem. Konstruktivistické muzeum si uvědomuje, že „pro návštěvníka neexistuje předem určený postup, což umožňuje různé učební modality" (Jůva, 2004 s. 128), které se odvíjejí od potřeb návštěvníků spíše než od povahy samotné expozice. Pro konstruktivistické muzeum je proto výhodou, když má jeho expozice více „záchytných bodů“, kterými je možné do edukačního procesu vstupovat, tedy když je expozice utvořena spíše jako otevřená entita než jako podél jedné trasy přísně strukturovaná narativní a edukační linka. Tento fakt se ostatně prolíná s předpokladem konstruktivistických teorií učení týkajících se toho, že učební témata nejsou jen ta předem definovaná, nýbrž se vyvíjejí v průběhu edukačního procesu (srov. Siebert, 2006; Taber, 2011). Volně strukturovaná expozice tak může muzejnímu pedagogovi napomoci lépe přizpůsobovat edukační aktivity potřebám i zájmům konkrétních návštěvníků, a to nejen $\mathrm{v}$ rámci přípravy programu před jeho začátkem, ale také $\mathrm{v}$ samotném průběhu edukačního procesu.

Moderní konstruktivistická muzea dle Heina (1999) zdůrazňují aktivní participaci učícího se jedince na procesu učení, na jeho aktivní konstrukci znalostí. Znalost, at' už ve smyslu té stávající a učebnímu procesu předcházející, tak i ve smyslu znalosti nově utvářené a získávané, je jedním z hlavních pojmů konstruktivistických teorií učení. Konstruktivistické muzeum (a stejně tak i konstruktivisticky orientovaná muzejní edukace) má dle Heina

15 Celkově zde lze sledovat posun zájmu moderního muzea, které se velkou měrou orientuje právě na diváka, oproti tradičnímu muzeu, $\mathrm{v}$ jehož centru pozornosti byl obvykle pouze samotný sbírkotvorný předmět. Vyvstat zde může debata mezi muzeology a muzejními pedagogy, kteří mohou ve vzájemné diskuzi zvýrazňovat bud' důležitost ochrany sbírek, a nebo naopak zájmy diváka. V moderním muzeu přitom obvykle již platí, že „V popředí by nadále nemělo stát získávání a konzervace předmětů, nýbrž jejich zprostředkování veřejnosti“ (Šobáňová, 2012a, s. 74). Předkládaný text přitom vychází z předpokladu, že pro edukační aktivity muzea je zaměřenost muzea na diváka zásadní, přesto však nemůže docházet ani k podceňování role muzeálií, které jsou již ze své podstaty hlavní složkou muzejní edukace. 
(1995b) stavět na dosavadních návštěvníkových znalostech v tom smyslu, že předkládané muzejní předměty a narativy by měl být návštěvník schopen včlenit do své stávající zkušenosti. Měl by mít pocit, že je zná a že se nějakým způsobem dotýkají jeho života, respektive má být schopen spojit objekty s tím, co již ví a díky tomu porovnat staré informace s těmi novými. Konstruktivistické muzeum má tedy podporovat poznání návštěvníků tak, že je přivádí „ke konstrukci nových poznatků o exponátech tím, že připomíná jejich předchozí znalosti a podněcuje jejich nové asociace" (Jagošová et al., 2010, s. 111).

Dalším důležitým pojmem je zkušenost, která je chápána stejně jako znalost $\mathrm{v}$ rámci binarity učebnímu procesu předcházející zkušenost a $\mathrm{v}$ rámci učebního procesu prožívaná zkušenost. Obě roviny zkušenosti ve výsledku tvoří jednotný, od sebe neoddělitelný celek. Zkušenost je v rámci konstruktivistických teorií učení vnímána tak, jak ji popisoval už Dewey - jako kontinuální proces. Dle Deweyho (cit. podle Hein, 2006) se zkušenost zakládá na minulosti i budoucnosti. Je to více než jen vjem konkrétního okamžiku, ačkoli i aktuální prožitek spojený s dojmem z muzea a v něm prožívaných situací hraje důležitou roli. Kromě současnosti ale zkušenost zahrnuje všechny dřívější vzpomínky a zážitky, stejně jako orientaci na budoucí cíle a záměry. Abychom pochopili zkušenost, musíme vzít v úvahu to, co se stalo dříve, a zároveň musíme zohlednit také možné budoucí akce a s nimi spojené kognitivní rámce, pro které tato minulost slouží jako jakýsi výchozí bod. Důležité tedy jsou nejen konkrétní podmínky dané situace a v ní odehrávající se zkušenosti, ale také to, co si do dané situace jedinec s sebou přináší, jak prožívanou zkušenost interpretuje i jak danou zkušenost využije v budoucnosti. Budoucnost je klíčová také pro možnost zhodnocení efektu edukace. Učební pokrok a přínos edukace lze totiž dle Sieberta (2006) vyhodnotit jen individuálně a až v pozdější praxi.

Zkušenost učícího se jedince je pro edukační proces klíčová. Ne každá zkušenost je ale dle Deweyho (srov. Dewey, 1997, s. 25-28; Hein, 2006) edukační zkušeností, respektive zkušeností s výchovně-vzdělávacím efektem. Pro Deweyho toto tvrzení znamená, že ne všechny zkušenosti vedou k morálnímu vývoji a formování vhodných postojů či schopností. Aby byla zkušenost edukační, měla by být kvalitní (nestačí př́ítomnost jakékoli zkušenosti) a nasměrovaná do budoucnosti (mělo by se jednat o kontinuální a vyvíjející se zkušenost, na kterou bude dítě v budoucnu navazovat). Dále by edukační 
zkušenost měla dítěti napomáhat rozvíjet kompetence k samostatnému aktivnímu učení a k tomu, aby bylo schopno rozeznat a ocenit sociální a morální důsledky toho, co se naučilo. Tento druh edukace pak nemůže být vystavěn pouze na obohacování jedincových znalostí a dovedností, nýbrž má zahrnovat také jeho morální růst. Hodnota vzdělávací aktivity závisí tedy nejen na intelektuálním obsahu, ale také na jejích sociálních důsledcích. Hodnotné pak jsou pro Deweyho ty výchovné zkušenosti, které vedou k dalšímu růstu jedince, ty které učí lidi intelektuálním a sociálním dovednostem potřebným pro život v participativní demokracii. Z pozice Deweyho expozice a muzejně-edukační programy mohou posílit demokracii tím, že budou rozvíjet kritické myšlení návštěvníkủ. Muzea podle něj mohou podporovat využívání kritického myšlení návštěvníků tím, že se budou ve své činnosti zabývat spornými otázkami a tématy, přičemž budou stát na straně sociální spravedlnosti a demokracie. To je podle Deweyho $(1997$, s. 18) žádoucí právě proto, že edukace má z jeho perspektivy připravovat mladé lidi na jejich budoucí život a zodpovědné jednání v něm. Ostatně sepětí edukace a s ní spojené zkušenosti s běžným životem je něčím přirozeným, nebot' každá zkušenost je dle Deweyho (1997, s. 38) ve svém konečném důsledku sociální záležitostí, zahrnuje lidský kontakt a komunikaci.

Orientace muzejní edukace na zkušenost se pojí s požadavkem sjednocení muzejní zkušenosti s životní zkušeností, který prosazoval Dewey a s nímž se ztotožňuje i Hein (2004). Aby byla návštěva muzea opravdu přínosná, je nutné včlenit ji do každodenního života jedince. To se může dít například tím, že expozice propojuje témata s tím, co návštěvníky zajímá a co se jich osobně dotýká, co běžně zažívají a řeší ve své každodenní realitě. Nalezení způsobu jak podporovat návštěvníkovu schopnost vztahovat bezprostřední výstupy muzejní zkušenosti ke každodennímu životu (tj. finální složka Deweyho pojetí zkušenosti) ale zůstává dle Heina (2004) pro dnešní muzea stále výzvou.

Praktické využití konstruktivistických teorií muzeem může znamenat také to, že se expozice a s nimi související edukační programy více zaměřují na procesy učení (učení je chápáno jako proces konstrukce významů a jeho průběh má být spjat s procesem objevování nových informací a vztahů mezi nimi ${ }^{16}$ ) než na obsah dané expozice a s ní spojené edukace. Jinak řečeno, mu-

16 Učení objevováním, v originále discovery learning, je koncept užívaný především Brunerem, který vycházejíc z konstruktivistických teorií učení předpokládá, že žáci v procesu učení používají své stávající znalosti a minulé zkušenosti, na jejichž základě odhalují další fakta a vztahy a konstruují tak znalosti nové (Jiang \& Perkins, 2013). Průcha a kol. (2009, s. 324-325) 
zejní pedagog spíše než na to, co má být naučeno, klade důraz na způsob, jakým to má být naučeno; spolu s tím se orientuje spíše na potřeby učících se jedinců, tj. návštěvníků, než na potřeby expozice, respektive snahy muzea prezentovat určitý narativ (Hein, 1995b). Právě fakt zdánlivého zanedbávání obsahu edukace může být kritiky konstruktivistického stylu učení vnímán rozporuplně. Nutné je však uvědomit si, že pokud tvrdíme, že je důležité věnovat pozornost způsobu edukace, do které má být učící se jedinec plně zaangažován, a tedy že věnujeme zvýšenou pozornost vlastní aktivitě učícího se jedince, neznamená to ještě, že obsah edukace není důležitý. Obsah samotný z edukačního procesu nemůže nikdy vypadnout, je jeho podstatnou součástí a $\mathrm{v}$ muzeu je $\mathrm{z}$ velké části vymezen povahou daných muzeálií. Spíše než nezohlednit obsah edukace jde o to upozornit, že je pro edukaci důležité, aby byl její obsah učícími se jedinci uchopován aktivně. Aby nešlo o pouhý pasivní př́ijem informací, ale o jejich aktivní vyhledávání, zkoumání, testování a podobně. V praxi to znamená, že v konstruktivistickém muzeu má návštěvník možnost vyzkoušet si interaktivní exponát a provést experiment v oblasti, jíž se výstava týká, a celý proces tak lépe pochopit, spíše než se jen pasivně dozvědět a naučit tradičně předávané informace týkající se daného jevu (srov. Hein, 1995, 1999, 2001).

Nyní už je jasné, že v rámci konstruktivistických teorií učení má pracovník muzea za úkol posilovat možnosti získání (kvalitních) zkušeností návštěvníků a maximalizovat jejich interakci s expozicí, at' už se jedná o interakci vizuální, orální či manuální. V edukační činnosti se tento aspekt projevuje ve dvou konkrétních př́stupech, které Hein (2006) přebírá od Deweyho. Jsou jimi takzvané „hands on“ a „minds on“ principy, které souvisejí s možností si dané jevy a předměty prakticky „osahat" a aktivně o nich přemýšlet. Tyto požadavky vyplývají z faktu, na který upozorňuje Dewey (1997, s. 39), když ř́ká, že zkušenost není vůči jedinci vnější. Není něčím, co se do něj vlije,

přitom řadí Brunerovo řízené objevování mezi tzv. učení řešením problémů, tj. mezi způsoby učení, které vyžadují kreativní přístup učících se jedinců $\mathrm{k}$ řešení problémových úloh a situací. To v podstatě odpovídá tomu, o čem píše Hein (1995b), když poukazuje na spjatost discovery learning s procesem aktivního získávání znalostí. Podle Heina (1995b) zastánci konceptu discovery learning věří, že pro získání znalostí je pro studenta mnohem důležitější a efektivnější to, když v kontextu s danými jevy získá vlastní osobní zkušenost, než když o nich pouze zprostředkovaně slyší (např. od pedagoga). Discovery learning ale Hein (1995b, s. 3) neklade na roveň konstruktivistickému stylu učení. Podobnost obou spočívá v orientaci přístupu na proces učení jako na aktivní proces učícího se jedince. Konstruktivismus je ale více než discovery learning orientován na pojetí znalostí jako konstruktu učících se jedinců, kdežto druhý př́stup pojímá znalosti více jako objektivně existující fenomény. 
ale jde o proces, ve kterém je sám jedinec aktivně angažován, jak fyzicky, tak i mentálně. Obzvláště v dnešní době nových technologií a prosazování se principu interaktivity $\mathrm{v}$ muzeu bychom totiž neměli zapomínat na to, že proces učení se v muzeu nemá podporovat pouze fyzickou aktivitu, ale také aktivní intelektuální činnost (Khaled, cit. podle Savicke \& Juceviciene, 2012, s. 78). Muzea by měla poskytovat prostor pro poznání, objevování, experimentování, ale i promýšlení, dotazování, diskutování, argumentování. Spolu s prožitým nevšedním zážitkem by učící se jedinci měli mít v muzeu možnost učit se $\mathrm{z}$ vlastní zkušenosti, $\mathrm{z}$ viděného a vykonaného spíše než jen slyšeného. Takto orientovaná edukace je pak dle Heina (1995b) jedním ze způsobů, jakým lze modifikovat chybné miskoncepce jedinců a nahradit je koncepcemi správnými.

I podle Witcombové (2006) by muzea měla využívat konstruktivistický pedagogický styl (srov. s Hein, 2006; Hooper-Greenhill, 2006), podle nějž je vzdělávání koncipováno jako proces prožívání světa, přičemž významy mají být aktivně vytvářeny učícím se jedincem, a ne pasivně a autoritativně předávány muzejním pracovníkem. Podle Witcombové (2006) expozice zohledňující konstruktivistické teorie učení využívají tzv. dialog interactivity, tedy jakýsi interaktivní dialog probíhající mezi návštěvníkem a expozicí. Expozice založené na interaktivním dialogu se snaží spojit s návštěvníkem prostřednictvím reprezentování aspektů jeho kulturního světa a pomocí používání otevřených narativů, tedy př́běhů, jejichž smysl není direktivně dán, nýbrž se na jeho tvorbě návštěvník aktivně podílí. Jinak řečeno, expozice (a s ní spojené edukační programy) nepředkládá autoritativní tvrzení, ale spíše návštěvníkovi poskytuje možnost srovnat ukazované objekty s vlastním každodenním životem. Návštěvník konstruuje významy a přisuzuje je expozici. Důraz je kladen na „ponoření se“ do výstavy a na zážitek.

$S$ tím že konstruktivistické teorie učení přiznávají návštěvníkovi muzea aktivní roli v procesu konstrukce významů, které v muzeu zprostředkovaně nachází, sehrávají důležitou roli v mírnění představ vnímajících muzeum jako ideologické místo, které vštěpuje svým návštěvníkům konkrétní názory a postoje. Kritické teorie nahlížejí prostředí muzeí a jejich expozic kriticky a shodují se na tom, že je muzeum vždy „produktem své vlastní doby a v mnoha svých rysech se projevuje jako mocenská, totalitní instituce, která konstruuje své teze v závislosti na společenských požadavcích či vládnoucí ideologii“ (Šobáňová, 2012b, s. 27). Jistě, muzea v minulosti prokázala svou ideologickou roli, např́íklad v době vzniku národních muzeí 
a celorepublikových i celosvětových výstav v 19. století, které sehrály důležitou roli v procesu konstrukce národní identity (srov. Holman, 2014; Jagošová et al., 2010; Šobáňová, 2012a). I dnes můžeme hovořit v kontextu muzejní edukace i samotných expozic o skrytém kurikulu, které prostřednictvím sdílených narativů pedagogové návštěvníkům předávají a jehož existenci je vhodné si uvědomit. Konstruktivistické teorie učení ale upozorňují na fakt, že se konstrukce př́běhů, postojů a zážitků v muzeu neodehrává pouze pod vlivem záměrů tvůrců muzejní expozice či pod vlivem cílů muzejního pedagoga, nýbrž se do ní promítají také specifické charakteristiky, znalosti a postoje každého návštěvníka, z čehož vyplývá, že jsou výsledky muzejní edukace subjektivní záležitostí, nikoli uniformně zkonstruovaným aktem. Není proto reálné, aby muzeum vštípilo všem svým návštěvníkům stejný pohled na realitu, naučilo je stejným informacím a podílelo se na rozvoji totožných postojů. ${ }^{17}$

Jak vidíme, konstruktivismus v muzejní edukaci zasahuje do celé řady aspektů edukační činnosti. Při aplikaci konstruktivismu do edukační reality ale nejde o pouhé nahodilé uplatnění některých jeho prvků, kterými mohou být např́iklad „hands on“ a „minds on“ aktivity, nebo zahrnutí několika muzejních narativů do edukačního procesu. Aby byl konstruktivismus v podobě konstruktivistických teorií učení v muzejní edukaci př́nosný, měl by si pedagog uvědomit jeho didaktické zázemí, resp. měl by důkladně zvažovat, jak jej didakticky uchopí a aplikuje do edukační praxe. Nad tím, jak didakticky potenciál konstruktivismu v edukačním procesu (potažmo právě i v muzejně-edukačním procesu) využít, se zamýšlí Štech (2003). Podle něj je hlavním cílem konstruktivisticky laděné edukace usnadnit učícím se jedincům osvojit si poznání. Tento proces ale nebude fungovat, pokud bude nahodilý. Naopak, vždy je podle Štecha nutné provést didaktickou analýzu učiva a zabývat se vytvořením přiměřených vyučovacích situací (tzn. uspořádáním prvků učiva, seskupením úkolů pro učící se jedince, zvolením edukačních nástrojů atd.). Při postupu konstruktivisticky orientované edukace pak Štech $(2003$, s. 75-80) doporučuje řídit se tzv. didaktickým kruhem ${ }^{18}$. Na jeho počátku stojí analýza základní pojmové struktury učiva. Jde o stanovení cíle edukace, určení toho, co si mají učící se jedinci v průběhu edukace osvojit (jaké

17 Výzkumy prováděné v muzeích např. ukazují, že návštěvník na základě svých dosavadních znalostí a postojů selektuje vybrané prvky expozice či jejího narativu, kterým věnuje pozornost, a interpretuje je spíše ve shodě s doposud osvojenými názory (srov. Dodd et al., 2012; Lloyd, 2014).

18 Ten přebírá od autorského týmu Giordan a de Vecchi a hovoří o něm v kontextu edukace dětí. 
poznatky, dovednosti, schopnosti či kompetence apod.). Druhým krokem je analýza stávajících mentálních reprezentací učících se jedinců, jejich prekonceptů. Jinými slovy, pedagog zjišt’uje, co o daném tématu jedincí vědí a v čem je jejich poznání neúplné či chybné. K zjištění těchto informací může muzejní pedagog s ohledem na charakteristiky dané skupiny využít celou řadu aktivit od kreslení komentovaných schémat a obrázků přes animační aktivity a písemné nebo ústní aktivity na zadané téma až po využití aktivit uvažování per negatio (tj. využívání otázek typu „Co by se stalo, kdyby...") a podobně. Třetím krokem je identifikace epistemologických překážek. Jde o zmapování poznávacích překážek v uchopování pojmů učícími se jedinci, které mají být v edukaci překonány. Čtvrtým krokem je definování specifických cílů vyučovací jednotky, za kterým následuje pátý krok - vytvoření vhodných vyučovacích situací. $\mathrm{V}$ této fázi pedagog vybírá vhodný učební materiál a pomůcky, prostorově a časově výukovou situaci plánuje a tak dále. Posledním krokem je fáze hodnocení, tedy vyhodnocení toho, zda v edukaci došlo k naplnění daných cílů, to jest zda se učící se jedinci naučili, co měli, osvojili si dané poznání či schopnosti a podobně. Ve škole tuto fázi často zastupují testy znalostí, v muzeu ale pedagog obvykle volí jiné formy ověřování naplnění daných cílů. Jeho možnosti jsou navíc omezené krátkým časovým rozsahem, který edukační jednotka muzejněedukačního programu má. Do muzea obvykle přicházejí skupinky jedinců, které muzejní pedagog předem nezná, setkává se s nimi poprvé, a to na dosti omezenou dobu (nejčastěji pohybující se okolo 60-120 minut). Pro muzejního pedagoga je proto obtížné zjišt'ovat podobu prekonceptů návštěvníků edukačního programu. Vhodným nástrojem, který umožňuje tyto informace poměrně rychle a snadno zjistit, přitom může být kromě výše zmíněných aktivit brainstorming nebo klasické dotazování se na předem připravené otázky.

\section{$5 \quad$ Prvky konstruktivistických teorií učení, které mohou být využívány $v$ edukační realitě muzea}

V tomto bodě již víme, co jsou to konstruktivistické teorie učení, jaké je jejich paradigmatické zázemí a jaký může být jejich potenciál v muzejní edukaci. Pro úplné pochopení dané problematiky a jejího uchopení v rovině praxe nyní studie dospívá ke svému hlavnímu cíli a na základě četby a analýzy odborné literatury, která byla představena na předešlých stranách, v následujícím výčtu vyvozuje a specifikuje několik základních prvků, skrze které mohou být konstruktivistické teorie učení v muzejní edukaci zaváděny do praxe. 
Výčet těchto prvků může muzejním pedagogům pomoci v koncipování konstruktivisticky orientovaného edukačního programu i v jeho následné evaluaci. V závorce za každým prvkem je uveden př́klad specifikace daného prvku, respektive otázka, která se pojí s jeho určením. Seznam otázek je jen ilustrativní, nikoli vyčerpávající. Jejich charakter slouží jako návodná ukázka, jak dané prvky zvažovat a skrze které konkrétní praktiky je do edukačního programu zavádět nebo evaluovat. Jednotlivé prvky jsou pro inspiraci doplněny také doporučením pro edukační praxi. Toto doporučení nastiňuje, jak konkrétně je možné prvky do praxe aplikovat. Př́́klady užití jsou uvedeny pro inspiraci a vycházejí ze znalosti expozice historické školní třídy, která se nachází na Zámku v Lešné u Valašského Meziř́ičí. Př́́klady jsou modelovány tak, jako by byl prostor expozice zvažován pro nový edukační program pro žáky základních škol, který nazvěme například „Jak vypadala škola na počátku 19. století a jak se v ní dětem žilo". Spíše než o vytvoření edukačního programu v celém jeho rozsahu jde ale jen o ilustrativní postřehy.

Podrobnější přehled užití prvků konstruktivistických teorií učení v muzejněedukační realitě pak reflektuje výzkumné šetření, které je popsáno v textu s názvem Využití konstruktivistických teorií učení v edukačním programu muzea: empirická prípadová studie (Kolaříková, v recenzním řízení). Pro ilustraci dané problematiky může přispět také výzkumná studie s názvem Videostudie v muzejněpedagogickém výzkumu: př́padová studie (Kolaříková, 2017), která ve svém výzkumu konstruktivistické prvky v edukaci také částečně reflektuje.

Podstatné je ještě připomenout, že nahodilé uplatnění těchto prvků v edukačním programu ještě neznamená, že má edukační proces konstruktivistický charakter. Použití těchto prvků musí být promyšlené, pedagog by měl přesně vědět, proč a s jakými cíli daný prvek v edukaci používá. Použití prvků by mělo být provázané, nikoli nahodilé a didakticky promyšlené. Například při využití prvku „hands on“ nejde jen o to, že si učící se jedinec v edukačním programu vyzkouší model historické přilbice. Bez kvalitního pedagogického zázemí by taková zkušenost nabývala zábavného, nikoli edukačního charakteru. Aby měla tato aktivita edukační charakter, je vhodné jedince seznámit s celým kontextem souvisejícím s daným artefaktem, například s jeho funkcí, historickým i sociálním kontextem a v neposlední řadě s jeho vztahem k edukačnímu tématu. Mělo by jít tedy o zkušenost, která nese nějaký poznatek a jejíž průběh je muzejním pedagogem promyšlen a (do určité míry) koordinován. 


\section{- Učící se jedinec jako aktivní činitel edukačního procesu}

Při evaluaci edukačního programu i při plánování zařazení tohoto konstruktivistického prvku do edukace můžeme zvažovat tyto otázky: Vnímá edukační program návštěvníka jako osobu aktivně se podílející na svém procesu učení? Nabízí edukační program učícímu se jedinci možnost samoregulace edukačního procesu? Zajímá se edukační program o stávající znalosti a zkušenosti návštěvníků? Zohledňuje edukační program potřeby, zájmy a charakteristiky učících se jedinců?

Doporučení pro edukační praxi: Tato kategorie úzce souvisí i s dalšími prvky konstruktivistického př́stupu využitého v edukaci. V praxi se může projevit třeba tak, že dá muzejní pedagog žákům možnost podrobněji se věnovat jednomu z vybraných exponátů, který si sami z pedagogem dané nabídky vyberou, nebo žákům umožní vybrat si postavu a s ní pojící se př́iběh, která je edukací provede (např. si mohou žáci vybrat, zda chtějí slyšet životní příběh Jozífka, který do školy docházel se svojí sestrou, se kterou spolu s rodiči bydlel u prarodičủ na malém statku, nebo o Františkovi, který byl z pěti dětí a s maminkou bydlel na místní faře, kde maminka pracovala apod.).

\section{- Ohled na specifické charakteristiky návštěvníků}

Při evaluaci edukačního programu i při plánování zařazení tohoto konstruktivistického prvku do edukace můžeme zvažovat tyto otázky: Bere expozice a edukační program v potaz specifické charakteristiky návštěvníků?

Doporučení pro edukační praxi: Muzejní pedagog se často se skupinkou žáků přicházejících využít edukační program muzea setkává poprvé. Při objednání tř́ídního kolektivu má ale možnost od jejich vyučujícího zjistit informace týkající se věku žáků, jejich počtu, může se zeptat, jaká motivace učitele s žáky do muzea přivádí a jaké informace o daném tématu mají (např. jak daleko jsou ve výuce dějepisu). Tyto informace pak pedagog zohlední při koncipování edukačního programu (je rozdíl pracovat s dětmi v první třídě a se žáky druhého stupně, jiné metody práce umožňuje práce s desetičlennou skupinkou, naopak pro velkou skupinu návštěvníků se budou lépe hodit jiné metody edukace).

\section{- Práce s novými i dř́ivějšími informacemi}

Při evaluaci edukačního programu i při plánování zařazení tohoto konstruktivistického prvku do edukace můžeme zvažovat tyto otázky: Jsou v rámci 
edukačního programu zjištovány stávající znalosti, zkušenosti a postoje návštěvníků? Nabízí muzeum návštěvníkům nové informace?

Doporučení pro edukační praxi: Prostor expozice nabízí možnost využití klasické tabule a křídy pro metodu brainstormingu, kterou by muzejní pedagog zjištoval stávající znalosti žáků týkající se života dětí na počátku 19. století. Učitel by zapisoval postřehy dětí odpovídajících na jeho otázky typu: Víte, jaké významné revoluce ovlivnily život lidí na přelomu 18. a 19. století? Jak tyto revoluce ovlivnily podobu života lidí? Kdy byla na našem území zavedena povinná školní docházka (kdo a proč ji zavedl)? Čím se lišila školní docházka dětí v minulosti od té vaší?

- Četnost a bohatost muzejních narativů př́tomných v expozici nebo využívaných $v$ muzejnědukačním programu

Při evaluaci edukačního programu i při plánování zařazení tohoto konstruktivistického prvku do edukace můžeme zvažovat tyto otázky: Předkládá muzeum / muzejní pedagog návštěvníkům jen jeden narativ, nebo využívá více narativů, díky kterým mohou návštěvníci svobodněji konstruovat svůj pohled na věc?

Doporučení pro edukační praxi: V edukačním programu se narativní linky mohou dotýkat nejen života žáků, ale také učitelů; v potaz může být brána odlišná situace rodin z nižších a vyšších společenských vrstev. Narativy se mohou týkat významných pedagogů (Komenský) a jejich vlivu na současnost, či běžných učitelů a jejich tehdejšího každodenního života.

- Otevřenost muzejních narativů prítomných $v$ expozici nebo využívaných v muzejněedukačním programu

Při evaluaci edukačního programu i při plánování zařazení tohoto konstruktivistického prvku do edukace můžeme zvažovat tyto otázky: Jsou muzejní narativy otevřeny více způsobům interpretace, nebo nabízejí striktní pohled na věc? Je téma expozice komplexní, nebo jsou informace jen částečné a vytržené $\mathrm{z}$ kontextu?

Doporučení pro edukační praxi: Edukační program by bylo vhodné zasadit do širšího kontextu celospolečenských změn, které se $v$ té době odehrávaly (vliv průmyslové revoluce a vliv Velké francouzské revoluce, nové technologie, stěhovaní lidí do měst, rozvoj nacionalismu, vzrůstající byrokracie 
apod.). Daná témata přitom nemusí být předkládána jako holý fakt (např. rozvoj technologií způsobil nakonec vzrůst ekologických problémů, povinná školní docházka přinesla rovný přístup ke vzdělávání), ale spíše jako problematika vhodná pro diskuzi (žáci dostanou za úkol zvážit, jaké klady a zápory byly s rozvojem technologií spojeny, diskutuje se problematika rovnosti ve vzdělávání - například problematika používání německého jazyka ve výuce, soukromých učitelů pro syny zámožných občanů apod.).

\section{- Zpracovávání témat týkajících se problémů současného světa}

Při evaluaci edukačního programu i při plánování zařazení tohoto konstruktivistického prvku do edukace můžeme zvažovat tyto otázky: Dotýká se edukační program současných společenských problémů a otázek?

Doporučení pro edukační praxi: Téma života dětí v 19. století může být přeneseno i do současnosti. Nemusí jít přitom jen o porovnání života tehdejších žáků (např jiné školní pomůcky, povinnost více pracovat, školní uniformy, kázeňské tresty) s životem současných žáků (tj. návštěvníků muzea), ale v závislosti na věku návštěvníků mohou být zvažovány hlubší (filozofické) otázky typu dnešního pocitu samozřejmosti nároku lidí na bezplatné a kvalitní vzdělání, diskuze faktu, že stále existují země, kde dostupnost základního vzdělání není samozřejmostí a podobně.

\section{- Otevírání diskutabilních a problémových témat}

Při evaluaci edukačního programu i při plánování zařazení tohoto konstruktivistického prvku do edukace můžeme zvažovat tyto otázky: Otevírá edukační program diskutabilní témata, nebo pracuje s informacemi jako s danými a neměnnými fenomény, které si mají návštěvníci osvojit spíše než promýšlet a diskutovat?

Doporučení pro edukační praxi: Následující dva prvky ukazují, jak jsou spolu jednotlivé konstruktivistické prvky provázány a jak se vzájemně prolínají. Výše zmíněná problematika (ne)dostupnosti základního vzdělání totiž může být příkladem diskutabilního tématu, stejně jako například problematika tělesných trestů ve školách či dětské práce. 


\section{- Snaha o tvorbu dialogu a vytváření diskuze}

Při evaluaci edukačního programu i při plánování zařazení tohoto konstruktivistického prvku do edukace můžeme zvažovat tyto otázky: Vybízí edukační program učící se jedince $\mathrm{k}$ tomu, aby diskutovali o svých názorech či předkládaných jevech?

Doporučení pro edukační praxi: Muzejní pedagog by měl využívat nejen technik monologu, ale také dialogu a diskuze. Dialog přitom nemusí probíhat jen mezi návštěvníkem a pedagogem, ale také mezi návštěvníky navzájem. Žáci tak např́íklad mohou dostat za úkol v rámci určitým způsobem definovaných skupinek diskutovat nad otázkou, zda má být základní vzdělání bezplatné a proč. Jedna ze skupinek přitom může dostat za úkol vymyslet argumenty pro to, že vzdělání má být bezplatné, druhá skupinka má naopak najít argumenty, proč by naopak vzdělání mělo být zpoplatněno. Výsledné argumenty jsou pak diskutovány všemi žáky. Aktivita má přitom rozvíjet nejen schopnost komunikace a argumentace, ale má také rozvíjet kritické myšlení žáků, kteř́ jsou v aktivitě nuceni najít vhodné argumenty pro obě varianty reality.

\section{- Snaha o podporu aktivní participace návštěvníků na edukačním procesu}

Při evaluaci edukačního programu i při plánování zařazení tohoto konstruktivistického prvku do edukace můžeme zvažovat tyto otázky: Je návštěvník vybízen k aktivnímu jednání, myšlení, zkoumání a podobně?

Doporučení pro edukační praxi: Muzejněedukační program by neměl být vystavěn jako pouhá prohlídka expozice. Žáci by měli mít možnost aktivně se účastnit vybraných úkolů, které se mohou zakládat na jejich diskuzi a argumentaci, i na hledání informací v textu (např v informačních panelech expozice), na tvorbě myšlenkových map, hraní rolí v rámci úkolů vycházejících z praxe dramatické výchovy, na manipulaci s předměty a tak dále. Využity mohou být různě aktivizační metody, metoda konstruktivního řešení problému a podobně.

\section{- Využívání principu „minds on“}

Při evaluaci edukačního programu i při plánování zařazení tohoto konstruktivistického prvku do edukace můžeme zvažovat tyto otázky: Vybízí edukační program návštěvníky k aktivnímu přemýšlení, bádání, řešení situací apod.? 
Doporučení pro edukační praxi: Pedagog dává žákům otázky a úkoly, nad kterými mají přemýšlet, např́klad hledat správnou odpověd' v textu. Nemusí jít ale jen o práci s textem, ale také s obrazem, grafem, o využití metody rozhovoru, kladení úkolu vymýšlet argumenty na zadané téma a podobně. Pedagog může využít metodu diskuze (panelová diskuze, řetězová diskuze, diskuze probíhající na základě konkrétních tezí apod.), metodu řešení problému, metodu rozboru situace a tak dále.

\section{- Využívání principu „hands on“}

Při evaluaci edukačního programu i při plánování zařazení tohoto konstruktivistického prvku do edukace můžeme zvažovat tyto otázky: Nabízí muzeum možnost manipulace s exponáty, experimentování apod.?

Doporučení pro edukační praxi: Muzejní pedagog může využít metod experimentu, laborování, žáci mohou mít možnost manipulovat s objekty (např. poznat jejich váhu, strukturu povrchu nebo funkci). Konkrétním prríkladem může být i obyčejná křída, se kterou už se dnes ne všichni žáci setkávají. Kř́da má specifické vlastnosti, snadno si od ní žáci mohou zašpinit oblečení, někteři žáci na ni mohou mít alergii a podobně - to vše může být žáky diskutováno.

\section{- Podpora rozvoje kritického myšlení návštěvníků}

Při evaluaci edukačního programu i při plánování zařazení tohoto konstruktivistického prvku do edukace můžeme zvažovat tyto otázky: Usiluje edukační program o rozvoj kritického myšlení jeho účastníkư? Podporuje edukační program rozvoj logického a reflektivního myšlení? Snaží se edukační program rozvíjet schopnost interpretace a analýzy v muzeu získávaných informací?

Doporučení pro edukační praxi: Muzejní pedagog může využít metod diskuze, brainstormingu, vědomé reflexe, didaktické hry a podobně. Jako inspirace mohou sloužit také tzv. RWCT metody (Reading and writing for critical thinking - Čtením a psaním ke kritickému myšlení).

\section{- Práce s postoji a hodnotami}

Při evaluaci edukačního programu i při plánování zařazení tohoto konstruktivistického prvku do edukace můžeme zvažovat tyto otázky: Snaží se edukační program rozvíjet postoje a hodnoty návštěvníků? 
Doporučení pro edukační praxi: Při práci s postoji a hodnotami může muzejní pedagog využít metodu hraní rolí, diskuze, může jít o práci s př́iběhem, ve kterém je oceněno něčí správné chování, nebo o řešení situací s problémovým morálním obsahem a tak dále. $\mathrm{V}$ neposlední řadě sem může patřit i učení prostřednictvím vlastního příkladu.

\section{- Rozvoj schopností a dovedností}

Při evaluaci edukačního programu i při plánování zařazení tohoto konstruktivistického prvku do edukace můžeme zvažovat tyto otázky: Rozvíjí edukační program akční či jiné schopnosti a dovednosti návštěvníků?

Doporučení pro edukační praxi: Edukační program může souviset s rozvojem jemné i hrubé motoriky (např. aktivity spojené s ručními pracemi, taneční aktivity, hra na živé sochy), s rozvojem percepce (poslech hudby, práce s obrazem apod.), představivosti, paměti, postřehu, spolupráce, může rozvíjet schopnost orientovat se v emocích vlastních i ostatních lidí a podobně.

- Rozvoj (pro)sociálních schopností, dovedností, postojů a interakcí

Při evaluaci edukačního programu i při plánování zařazení tohoto konstruktivistického prvku do edukace můžeme zvažovat tyto otázky: Rozvíjí edukační program komunikační dovednosti návštěvníků? Využívá edukace skupinové práce? Podporuje téma expozice či edukačního programu rozvoj prosociálních postojů?

Doporučení pro edukační praxi: Muzejní pedagog může žákům zadat skupinovou práci, při níž žáci nevykonávají aktivity individuálně, ale ve spolupráci s ostatními (nejmenší skupinou je dvojice). Skupiny mohou vznikat spontánně, kdy si žáci vyberou, s kým chtějí ve skupince být. Složení skupin ale může být určeno také pedagogem, což umožní spolupráci a komunikaci žáků, kteří se spolu běžně do kontaktu tolik nedostanou. $V$ rámci těchto aktivit může pedagog využít také inscenační metody, metodu didaktické hry a podobně.

\section{- Zasazení edukace v sociálním, kulturním a situačním kontextu}

Při evaluaci edukačního programu i při plánování zařazení tohoto konstruktivistického prvku do edukace můžeme zvažovat tyto otázky: Jsou muzejní narativy zasazeny do kontextu každodenního života návštěvníků? 
Doporučení pro edukační praxi: S každodenním životem žáků pocházejících z dané lokality expozice historické třídy souvisí např́íklad tak, že se na zámku v minulosti školní tř́dy opravdu nacházely. Tuto skutečnost spjatosti expozice s místem života žáků může edukační program využít.

\section{- Zohlednění (žité) zkušenosti návštěvníků}

Při evaluaci edukačního programu i při plánování zařazení tohoto konstruktivistického prvku do edukace můžeme zvažovat tyto otázky: Získávají v muzeu návštěvníci pozitivní zkušenost, která je obohacuje a je pro ně př́ijemná? Mohou zkušenost prožitou v muzeu návštěvníci nějak uplatnit ve svém každodenním životě?

Doporučení pro edukační praxi: Edukace $\mathrm{v}$ muzeu má být pro návštěvníky nejen poučná, ale také zábavná. Návštěvníci se musí v muzeu cítit bezpečně a komfortně (např. mohou využít toaletu v př́ipadě potřeby, aktovky a bundy si mohou ponechat $\mathrm{v}$ šatně nebo uzamykatelných skř́ńnkách). Znalosti, které si z muzea žáci odnesou, by pro ně měly být užitečné a využitelné i pro budoucí praxi. $V$ tomto případě může jít například o uvědomění si toho, jaký vliv měla průmyslová revoluce nejen na život tehdejších lidí, ale nás všech v současnosti (nejen ekologické problémy, ale i vznik národních států, rozvoj sítí komunikace, možnost sociálního vzestupu s ohledem na vlastní úsilí a úspěchy člověka apod.).

- Maximální využití potenciálu prostředí muzea jako specifického učebního prostredí

Při evaluaci edukačního programu i při plánování zařazení tohoto konstruktivistického prvku do edukace můžeme zvažovat tyto otázky: Provedl muzejní pedagog v kontextu expozice pedagogizaci prostředí? Pracuje muzejní pedagog s muzejními exponáty s důrazem na zohlednění jejich muzeality a kulturní hodnoty?

Doporučení pro edukační praxi: Muzejní edukace by měla vždy vycházet z př́itomných muzeálií. Pro konkrétní edukační program může být př́nosné využití dobových školních lavic. Ty poslouží nejen jako autentický doklad minulosti, ale při jejich využití (děti se do nich mohou posadit) je možné lépe navodit dobovou atmosféru a podpořit emoční vnímání dětí. Žáci navíc získávají autentickou zkušenost toho, jak se žákům v lavicích dříve sedělo, mohou porovnat tuto zkušenost se svou každodenní zkušeností ze sezení 
v současných lavicích a podobně. V neposlední řadě může sezení v lavici dětem poskytnout také prostor pro odpočinek i pohodlné místo k výkonu úkolů, při nichž mají něco psát.

\section{- Role muzejního pedagoga a jeho zvládnutí edukačního procesu}

Při evaluaci edukačního programu i při plánování zařazení tohoto konstruktivistického prvku do edukace můžeme zvažovat tyto otázky: Zohledňuje pedagog mentální rámce, dosavadní znalosti a další specifika žáků? Funguje muzejní pedagog jako facilitátor edukačního procesu?

Doporučení pro edukační praxi: Edukace $\mathrm{v}$ muzeu by měla být vždy didakticky ukotvená, pedagog stanovuje její cíle a ví, čeho chce pomocí zvolených edukačních metod dosáhnout, celá edukace je koncipována s ohledem na věk a další specifika návštěvnické skupiny, která se v muzeu neučí nahodile, nýbrž pod vedením muzejního pedagoga. Ten je pro žáky nejen průvodcem muzea, ale i facilitátorem celého edukačního procesu (poskytuje instruktáž k edukačním úkolům a aktivitám, zprostředkovává nové informace, podporuje vzájemný dialog apod.).

\section{Závěr}

Konstruktivistické teorie učení nejsou jediným modelem učení, který může být v muzeu využíván, jejich využití ale může, jak se studie snažila ukázat, muzejní edukaci obohatit. Jedná se o teorie aktuální, které v mnoha ohledech odpovídají současným edukačním trendům i aktuálním společenskovědním přístupům, které se v kontextu zkoumání sociální reality zrcadlí především $\mathrm{v}$ paradigmatu sociologického konstruktivismu. Ten stejně jako konstruktivistické teorie učení vnímá sociální aktéry jako aktivní (byt' ne vždy vědomě aktivní) konstruktéry sociální reality a spolu s tím i procesu učení a získávání informací a vědění jako takového. Jsou to totiž samotní učící se jedinci a jejich kognitivní rámce, které se podílejí na konstrukci vědění (vzpomeňme na důležitost propojení myšlenkových koncepcí radikálního a sociálního konstruktivismu, o kterých byla ve studii řeč). Konstruktivistické teorie učení zároveň reagují na současné vize demokratické společnosti tím, že si kladou za cíl rozvíjet jedince schopného kvalitního a zodpovědného života na rovině soukromé i společenské. Klíčovým pojmem těchto teorií je kritické myšlení a jeho rozvoj. A právě rozvoj kritického myšlení stojí v centru pozornosti současné pedagogiky, respektive jde o společenský zájem jako takový. 
Pro konstruktivistické teorie učení je klíčový důraz na potřebu aktivního zapojení učících se jedincủ do procesu edukace. Ve snaze aktivizovat učící se jedince volí konstruktivisticky orientovaná edukace nejrůznější aktivizující metody a orientuje se nejen na rozvoj znalostí, ale také postojů, hodnot, (klíčových) kompetencí, (akčních) dovedností a nejrůznějších schopností včetně kognitivních a metakognitivních strategií, které se úzce pojí s rozvojem kritického myšlení. Zároveň si tyto teorie uvědomují, že nejde pouze o to aktivizovat učící se jedince v edukačním procesu, ale také o to zohlednit v něm jejich dosavadní znalosti, postoje a zkušenosti. Učící se jedinci jsou totiž aktivními činiteli své edukace nejen ve smyslu aktivního jednání a myšlení v průběhu edukačních aktivit, ale také ve smyslu individuální konstrukce významů, znalostí a postojů, které během edukace konstruují a které jsou vždy ovlivněny jejich dosavadními prekoncepty. Konstruktivisticky orientovaná edukace proto nepracuje pouze s novými informacemi, ale také se stávajícími znalostmi a zkušenostmi lidí. Obrací se přitom nejen do minulosti (co už jedinci vědí) a do budoucnosti (k čemu jim nové znalosti, schopnosti a dovednosti budou, jak je budou moci včlenit do svého každodenního života), ale zaměřuje se i na současnou zkušenost například tím, že se snaží učícím se jedincům zprostředkovat příjemně strávené chvíle prožité $v$ přátelském a komfortním prostředí, tedy v prostředí, které bere ohled na základní lidské potřeby a zároveň $v$ edukaci zohledňuje specifické potřeby a zájmy dané skupiny a jejích členů.

Cílem textu nebylo avizovat konstruktivistické teorie učení a jejich prvky jako jediné možné modely edukace. Text se spíše snažil poukázat na možné př́nosy využití těchto teorií v edukační praxi a speciálně pak v edukaci probíhající v prostředí muzea, pro které by mohlo být snadnější tyto teorie aplikovat do praxe, př́padně je následně evaluovat. Muzea mohou totiž definovat mohou definovat své edukační cíle volněji než školy, které jsou vázány rámcovými vzdělávacími programy a definovaným sumářem oborových znalostí. Muzea jsou spíše omezena svým konkrétním zaměřením a podobou svých sbírek. Ve svých edukačních cílech mohou kreativně volit nejen cíle související s RVP či cíle orientované na zisk předem definovaných informací. Specifikem muzeí je totiž fakt, že ze své podstaty disponují prostorem bohatým na kulturní významy, které reprezentují konkrétní muzeálie, a kultura (reprezentovaná vystavenými kulturními artefakty apod.) se tak v jejich prostředí stává edukačním prostředkem či fenoménem, který je s procesem edukace a kultivace úzce spjat. 
Mimoto muzea disponují prostorem využitelným pro hravý a zábavný způsob učení, prostorem, kde edukace neprobíhá v lavicích (tedy v př́ípadě, že muzejní pedagog nevyužívá pouze lektorských tříd, které některá muzea mají), ale $\mathrm{v}$ expozici, která může vybízet návštěvníky nejen $\mathrm{k}$ pohybu, ale také $\mathrm{k}$ aktivnímu myšlení a jednání, a kterou v ideálním případě vede muzejní pedagog, který může být pro žáky nevšedním a atraktivním facilitátorem edukace. Pro muzejního pedagoga přitom může být snadnější plnit úlohu facilitátora edukačního procesu, než jak je tomu u učitele ve škole. Ve škole totiž může být učitel více svázán s konkrétními, očekávanými a často i více formalizovanými edukačními postupy, úkoly i stereotypy, a to jak z pozice vlastní osobnosti, tak z pozice nadřízených, kolegů či rodičủ žáků a podobně. Dủležité je podotknout, že role pedagoga a jeho význam se v konstruktivismu nevytrácí. Schopnosti pedagoga jako průvodce edukačním procesem i jako jeho realizátora, který celý edukační proces didakticky zastřešuje, stojí také v centru pozornosti těchto teorií, nebot' konstruktivistické paradigma si uvědomuje roli všech do edukace angažovaných subjektů a komponentů, mezi které vedle role pedagoga patří i dané prostředí, jeho atmosféra a tak dále.

Konstruktivistické muzeum dle Heina (1995b) často klade větší důraz na průběh edukačního programu, respektive na proces učebního procesu, než na jeho obsah. V konsekvencích vize této studie by ale nemělo jít o to, že se obsah z konstruktivistické edukace vytrácí. To by ostatně neodpovídalo ani specifikům muzejní edukace, která vychází z muzeálií a je na ně svým obsahem dominantně navázána (ne ale nutně výhradně). $\mathrm{V}$ konstruktivisticky laděné muzejní edukaci by dle mého názoru mělo jít spíše než o potlačení obsahu či jeho zanedbání o fakt, že obsah je částečně utvářen i učícími se jedinci. Ti se na něm mohou v ideálním př́ípadě podílet například volbou témat a podtémat, které je v muzeu a probíhající edukaci zajímají, a kterým proto chtějí věnovat svou pozornost.

Studie postupně nastínila potenciální přínos, který tkví v možnostech využití konstruktivistického paradigmatu $\mathrm{v}$ muzejní edukaci včetně diskuze možných výtek $\mathrm{k}$ němu směřujících. Hlavním cílem, ke kterému studie postupně směřovala, bylo ukázat, jak konkrétně se v muzejní edukaci může konstruktivistický edukační styl uplatnit, respektive nastínit, jaké konkrétní podoby mohou prvky konstruktivistických teorií učení $\mathrm{v}$ muzejní edukaci nabývat a jak je možné aplikovat je do praxe. Jasné vymezení konkrétních prvků konstruktivistických teorií učení využitelných v edukační praxi totiž 
v odborné literatuře chybí. Tento fakt pak pedagogům ztěžuje možnost zavádět je do praxe a následně jejich využití v muzeu evaluovat. Studie proto ve své páté kapitole představila seznam nejdůležitějších prvků konstruktivistických teorií učení, ke kterým autorka na základě studia odborné literatury dospěla. Konkrétně jde o potřebu uvědomit si, že je učící se jedinec aktivním činitelem edukačního procesu - a právě tak konstruktivistická edukace učícího se jedince pojímá. Konstruktivisticky orientovaná edukace vždy bere $\mathrm{v}$ potaz specifické charakteristiky skupiny, která se v muzeu vzdělává. Zvažovány jsou přitom brány i dosavadní znalosti a zkušenosti návštěvníků, na které chce muzejní pedagog postupně navazovat znalostmi novými. Spolu s tím se konstruktivisticky orientovaná edukace dotýká každodenního života učících se jedinců, což v praxi znamená, že pro edukaci vybírá pro návštěvníky zajímavá a důležitá témata a zasazuje je do kontextu života lidí v daném geografickém, kulturním a sociálním prostředí, které má své specifické charakteristiky i problémy. Narativy, se kterými muzejní edukace vycházející z principů konstruktivistických teorií učení pracuje, by měly být bohaté na významy a otevřené možnosti jejich diskuze, což znamená, že spíše, než že by nabízely jediný objektivní pohled na realitu, vybízejí návštěvníky k tvorbě vlastních úsudků a pohledů na věc. Konstruktivisticky ukotvená edukace se snaží vytvářet prostor pro diskuzi a dialog, který podporuje rozvoj kritického myšlení, komunikačních i dalších schopností a dovedností. Rozvoj kritického myšlení je přitom součástí principu „minds on“, tedy snahy nejrůznějšími prostředky aktivizovat myšlení učících se jedinců. $V$ takzvaném konstruktivistickém muzeu se přitom objevuje snaha podporovat nejen myšlení, ale i jednání lidí, které vycházejí z principu „hands on“, jež prosazuje myšlenku efektivity možnosti manipulace s exponáty. Tyto prvky se přitom v edukaci mohou vzájemně prolínat v metodách experimentu, didaktické hry i v dalších aktivitách. Spolu s řešením otázek současného světa konstruktivistický model učení nabízí prostor pro rozvoj (prosociálních) postojů a hodnot, které mohou být mimo jiné utvářeny $v$ rámci skupinové práce. I ta je totiž důležitým rysem konstruktivistického stylu učení, který vnímá skupinovou kooperaci a komunikaci nejen jako žádoucí cíl edukace, ale i její vhodný prostředek.

\section{Literatura}

Al-Saggaf, Y., \& Williamson, K. (2006). Doing ethnography from within a constructivist paradigm to explore virtual communities in Saudi Arabia. Qualitative Sociology Review, II(2), 5-20.

Alieva, D. (2016). Kto sa bojí sociálneho konštruktivizmu. Sociální studia, 3(2016), 37-60. 
Berger, P., \&Luckmann, T. (1999). Sociální konstrukce reality. Brno: CDK.

De Corte, E. (2012). Constructive, self-regulated, situated and collaborative learning: An approach for the acquisition of adaptive kompetence. Journal of Education, 192(2/3), 33-47.

Dewey, J. (1997). Experience and education. New York: TouchstoneBook.

Dodd, J., Jones, C., Sawyer A., \& Tseliou, M. (2012). Voices from the museum: Qualitative researchcConducted in Europe's national museums. EuNaMus Report No 6. (Linköping University Interdisciplinary Studies 17). Sweden: Linköping University ElectronicPress.

Falk, J. H., Dierking, L. D., \& Adams, M. (2006) Living in a learning society: Museums and freechoice learning. In S. Macdonald (Ed.), A companion to museum studies (s. 323-339). Malden Blackwell Publishing.

Hein, G. E. (1995). Evaluating teaching and learning in museums. In E. Hooper-Greenhill (Ed.), Museum: Media: Message (s. 189-203). London: Routledge.

Hein, G. E. (1995b). The constructivist museum. Journal for Education in Museums, 16(1995), 21-23.

Hein, G. E. (1999). Is meaning making constructivism? Is constructivism meaning making? The Exhibitionist, 18(2), 15-18.

Hein, G. E. (2001). The challenge and significance of constructivism. In Hands-On! Europe Conference (s. 35-42). London.

Hein G. E. (2004). John Dewey and museum education. Curator, 47(4), 413-427.

Hein, G. E. (2006). John Dewey's „Wholly Original Philosophy“ and its significance for museums. Curator, 49(2), 181-203.

Holman, P. (2014). Úvod do muzeologie. In J. Dolák, \& P. Holman, et al. (Eds.), Základy muzejní pedagogiky: studijní texty (s. 11-23). Brno: Moravské zemské muzeum.

Hooper-Greenhill, E. (2006). Studying Visitors. In S. Macdonald (Ed.), A companion to museum studies (s. 362-376). Malden Blackwell Publishing.

Jagošová, L., Jůva, V., \& Mrázová, L. (2010). Muzejní pedagogika: metodologické a didaktické aspekty muzejní edukace. Brno: Paido.

Jiang, X., \& Perkins, K. (2013). A conceptual paper on the application of the picture word inductive model using bruner's constructivist view of learning and the cognitive load theory. Interdisciplinary Journal of Teaching and Learning, 3(1), 8-17.

Jůva, V. (2004). Dětské muzeum: edukační fenomén pro 21. století. Brno: Paido.

Kaščák, O. (2002). Je pedagogika připravena na změny perspektiv? Rekontextualizace pohledů na výchovně-vzdělávací proces pod vlivem radikálního individuálního konstruktivismu a postmoderního sociálního konstruktivismu. Pedagogika, 52(4), 388-414.

Kolař́ková, V. (2017). Videostudie v muzejněpedagogickém výzkumu: př́ípadová studie. Museologica Brunensia, 6(2), 56-67.

Kolaříková, V. (2018). Sociologie vědění jako cesta k promýšlení sociálních praktik. Sociální pedagogika, 6(1), 11-27.

Kolaříková, V. (v recenzním řízení). Využití konstruktivistických teorií učení v edukačním programu muzea: empirická př́ípadová studie.

Kwan, Y. W., \& Wong, A. F. L. (2015). Effects of the constructivist learning environment on students' critical thinking ability: Cognitive and motivational variables as mediators. International Journal of Educational Research, 70(2015), 68-79. 
Lloyd, K. (2014). Beyond the rhetoric of an "inclusive national identity": Understanding the potential impact of Scottish museums on public attitudes to issues of identity, citizenship and belonging in an age of migrations. Cultural Trends, 23(3), 148-158.

Lokajíčková, V. (2014). Metakognice - vymezení pojmu a jeho uchopení v kontextu výuky. Pedagogika, 64(3), 287-306.

Mannheim, K. (1991). Ideologie a utopie. Bratislava: Archa.

Maříková, H., Petrusek, M., \& Vodáková, A. (1996). Velký sociologický slovník. I, A-O. Praha: Karolinum.

Ministerstvo školství, mládeže a tělovýchovy České republiky. (2005). Rámcový vzdělávací program pro základní vzdělávání. Dostupné z http://www.msmt.cz/vzdelavani/skolstvi-vcr/skolskareforma/ramcove-vzdelavaci-programy

Mlynář, J., \& Paulíček, M. (2016). Vlastní problém sociologické teorie spočívá v praxi. Interview s profesorem Iljou Šrubařem. Sociální studia, 13(3) 73-81.

Murawska-Muthesius, K., \& Piotrowski, P. (Eds.). (2015). From museum critique to thecritical museum. United Kingdom: Ashgate Publishing Company.

Pasch, M., Gardner, T. G., Langerová, G. M., Starková, A. J., \& Moodyová, Ch. D. (1998). Od vzdělávacího programu k vyučovací hodině. Praha: Portál.

Paulíček, M., Mlynář, J., \& Vido, R. (2016). Sociální konstruktivismus padesátiletý. Sociální studia, 13(3) 7-9.

Průcha, J. (2002). Moderní pedagogika. Praha: Portál.

Průcha, J., Walterová, E., \& Mareš, J. (2009). Pedagogický slovník. Praha: Portál.

Savicke, J., \& Juceviciene, P. (2012). Educating students in museums: Possibilities for forming personal learning environments. Social Sciences, 4(78), 75-83.

Scheer, A., Noweski, Ch., \& Meinel, Ch. (2012). Transforming constructivist learningin to action: Design thinking in education. Design and Technology Education: An International Journal, 17(3), 8-19.

Siebert, H. (2006). Der Konstruktivismus - viel Lärm um nichts? Eine erkenntnistheoretische Kontroverse und ihre Folgen. Zeitschrift für Religions- und Geistesgeschichte, 58(1), 49-61.

Singule, F. (1991). Americká pragmatická pedagogika: John Dewey a jeho američtí následovníci. Praha: Státní pedagogické nakladatelství.

Stam, H. J. (2001). Introduction: Social constructionism and its critics. Theory \& Psychology, 11(3), 291-296.

Šíp, R. (2015). Pedagogika a paradigmatický obrat v metodologii a teorii. Pedagogická orientace, 25(5), 671-699.

Šobáňová, P. (2012a). Edukační potenciál muzea. Olomouc: Univerzita Palackého v Olomouci.

Šobáňová, P. (2012b). Kritické teorie muzea - podnět k reflexi. Muzeum, 50(2), 26-28.

Šobáňová, P. (2012c). Muzejní edukace. Olomouc: Univerzita Palackého v Olomouci.

Štech, S. (2003). Vzdělávací programy mají umožnit edukaci aneb Brána mysli otevřená. In A. Brabcová (Ed.), Brána muzea otevřená (s. 66-85). Praha: JUKO.

Štech, S. (2013). Když je kurikulární reforma evidence-less. Pedagogická orientace, 23(5), 615-633.

Taber, K. S. (2011). Constructivism as educational theory: Contingency in learning, and optimally guided instruction. In J. Hassaskhah (Ed.), Educational theory (s. 39-61). New York: Nova. 
Vollmers, B. (1997). Learning by Doing: Piagets konstruktivistische Lerntheorie und ihre Konsequenzen für die pädagogische Praxis. Internationale Zeitschrift für Erziehungswissenschaft, 43(1), 73-85.

Weber, M. (2009). Metodologie, sociologie a politika. Praha: Oikoymenh.

Wilde, M., \& Urhahne, D. (2008). Museum learning: A study of motivation and learning achievement. Journal of Biological Education, 42(2), 78-83.

Witcomb, A. (2006). Interactivity: Thinking beyond. In S. Macdonald (Ed.), A companion to museum studies (s. 354-361). Malden Blackwell Publishing.

Zormanová, L. (2012). Výukové metody v pedagogice. Praha: Grada.

\title{
Autorka
}

Mgr. et Mgr. Veronika Kolaříková, Masarykova univerzita, Pedagogická fakulta, Poříčí 9, 63900 Brno, email: kolarikova.veronika@mail.muni.cz

\section{Constructivist learning theories and their application in the educational reality of a museum}

\begin{abstract}
Education is not only a part of the school environment, but also other institutions, among which the museums are now largely ranked. Museums can educate and cultivate their visitors, where constructivist learning theories seem to be an appropriate anchor of museum educational activities. These are based on the constructivist paradigm of social sciences and classical thoughts, which is the representative of Dewey pragmatism. The introduction of constructivist theories of learning, their anchoring in a constructivist paradigm and their subsequent application to the environment of the museum form the key axis and theme of the presented study. The main objective of the study is not only to introduce constructivist-oriented museum education, but in particular to identify and define the basic elements of the constructivist theory of learning that may be useful (not only) for museum and its educational reality, both its practice and subsequent evaluation.
\end{abstract}

Keywords: constructivism, constructivist learning theory, education, museum 